Instituto de Psicologia da Universidade de São Paulo

Sandro Aparecido Mazzio

\title{
As múltiplas narrativas na constituição da identidade latino americana
}

São Paulo 
Sandro Aparecido Mazzio

\section{As múltiplas narrativas na constituição da identidade latino americana}

(Versão original)

Dissertação apresentada ao Instituto de Psicologia da Universidade de São Paulo para obtenção do título de Mestre em Psicologia Social

Área de concentração: Psicologia Social

Orientadora: Prof ${ }^{\mathrm{a}}$ Dr ${ }^{\mathrm{a}}$ Sylvia Leser de Mello

São Paulo

2015 


\section{AUTORIZO A REPRODUÇÃO E DIVULGAÇÃO TOTAL OU PARCIAL DESTE TRABALHO, POR QUALQUER MEIO CONVENCIONAL OU ELETRÔNICO, PARA FINS DE ESTUDO E PESQUISA, DESDE QUE CITADA A FONTE.}

Catalogação na publicação

Biblioteca Dante Moreira Leite

Instituto de Psicologia da Universidade de São Paulo

Mazzio, Sandro Aparecido.

As múltiplas narrativas na constituição de uma identidade latinoamericana / Sandro Aparecido Mazzio ; orientadora Sylvia Leser de Mello. -- São Paulo, 2015.

$66 \mathrm{f}$.

Dissertação (Mestrado - Programa de Pós-Graduação em Psicologia. Área de Concentração: Psicologia Social e do Trabalho ) Instituto de Psicologia da Universidade de São Paulo.

1. América Latina 2. Identidade 3. Latinidade 4. Literatura 5. Psicologia social I. Título.

BF698 


\section{As múltiplas narrativas na constituição da identidade latino americana}

Dissertação apresentada ao Instituto de Psicologia da Universidade de São Paulo para obtenção do título de Mestre em Psicologia Social

Área de concentração: Psicologia Social

Aprovado em: de de

Banca Examinadora

Prof Dr: Instituição:

Julgamento: Assinatura:

Prof Dr: Instituição:

Julgamento: Assinatura:

Prof Dr: Instituição:

Julgamento: Assinatura:

São Paulo 
Ao meu pai e írmã in memorian 


\section{Agradecimentos}

Espero não esquecer de ninguém, caso isso aconteça, por favor me desculpem.

Quero muito agradecer aos grandes e constantes amigos de caminhada.

Àqueles que de tão constantes, deixaram de ser apenas amigos e amigas.

Vocês sabem de que estou falando, não é?

Um grande e fraterno abraço em:

Xandó, Piquet, Luisão, Fabiano, Marião, Marcelo, Heavy, Edu.

As melhores amigas que alguém poderia pedir:

Conceição, Cida, Enéida, Pat e Mirna.

Prof $^{\text {a }}$ Sylvia pela paciência e confiança.

Nalva, Fátima, Sônia e Tânia por estarem sempre cuidando de todo mundo.

Por fim, mas não menos importante,

Minha Mãe e Ceci por estarem sempre comigo. 
Soy... Soy lo que dejaron

Soy toda la sobra de lo que se robaron

Un pueblo escondido en la cima

Mi piel es de cuero, por eso aguanta cualquier clima

Soy una fábrica de humo

Mano de obra campesina para tu consumo

Frente de frío en el medio del verano

El amor en los tiempos del cólera, mi hermano!

Soy el sol que nace y el día que muere

Con los mejores atardeceres

Soy el desarrollo en carne viva

Un discurso politico sin saliva

Las caras más bonitas que he conocido

Soy la fotografía de un desaparecido

La sangre dentro de tus venas

Soy un pedazo de tierra que vale la pena

Una canasta con frijoles, soy Maradona contra Inglaterra

Anotándote dos goles

Soy lo que sostiene mi bandera

La espina dorsal del planeta, es mi cordillera

Soy lo que me enseñó mi padre

El que no quiere a su patría, no quiere a su madre

Soy américa Latina, un pueblo sin piernas, pero que camina

Oye!

Calle 13, Latinoamerica 


\section{Resumo}

Resumo em português

Em um primeiro momento, o presente trabalho procura analisar de maneira crítica o processo de constituição de uma identidade latino-americana a partir da historicização da ideia e do nome América Latina. Ao acompanharmos esse processo, do período colonial até nossos dias, apontamos para o seu caráter dinâmico, resultado das relações de poder estabelecidas ao longo tempo. Em nossa análise, daremos ênfase aos períodos de crise ou ruptura de um determinado discurso identitário. Em um segundo momento, iremos buscar ao longo da trilogia "Memória do Fogo" - obra em que o escritor uruguaio Eduardo Galeano, a partir de pequenos fragmentos narrativos, constrói um grande memorial das Américas - elementos que possam justificar o conceito de identidade latino-americana ou a necessidade de elaborarmos um outro que seja mais representativo de nossa diversidade sócio-cultural.

Palavras-chaves: América Latina. Identidade. Latinidade. Literatura. Psicologia Social. 


\section{Abstract}

In a first moment, this paper seeks to analyze critically the process of constitution of a Latin American identity from the historicizing of the idea and of the name of Latin America. to the we accompany this process, from the colonial period to until our day, we point to its dynamic nature, the result of power relations established over time. In our analysis, we will emphasize the periods of crisis or rupture of a certain discourse identity. In a second moment, we will seek along the "Memory of Fire" trilogy - work in which the Uruguayan writer Eduardo Galeano, from narrative small fragments, builds a great memorial of the Americas - elements that could justify the concept of identity Latin American need for elaborate or one that is more representative of our socio-cultural diversity.

Keyword: Latin America. Identity. Latin. Literature. Social Psycology. 


\section{Sumário}

INTRODUÇÃO $\ldots \ldots \ldots \ldots \ldots \ldots \ldots \ldots$

1.1 Uma identidade social $\ldots \ldots \ldots \ldots \ldots \ldots$

1.2 Uma justificativa literária $\ldots \ldots \ldots \ldots$

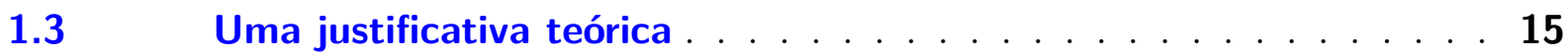

2 DOS OLHARES SOBRE A AMÉRICA LATINA . . . . . . . . 19

$2.1 \quad$ Um breve prelúdio . . . . . . . . . . . . . . . 19

$2.2 \quad$ Para contextualizar o problema . . . . . . . . . . . . 19

$2.2 .1 \quad$ Outros momentos de crise . . . . . . . . . . . . . . . . 21

2.2.2 O nascimento: um instante entre a vida e a morte . . . . . . . . . . 23

2.2.2.1 Das Índias Ocidentais à América: sob o domínio do Outro . . . . . . . . . . . . . . 26

2.2.3 Da independência à consolidação dos Estados-Nações . . . . . . . . . . . 27

$2.2 .4 \quad$ Da Hispanoamérica à América Latina . . . . . . . . . . . . . . . 28

2.2.4.1 Uma origem ainda controversa . . . . . . . . . . . . . . . . . . . . 29

2.2.4.2 Da ideia de latinidade à ideia latina $\ldots \ldots \ldots . \ldots . \ldots$

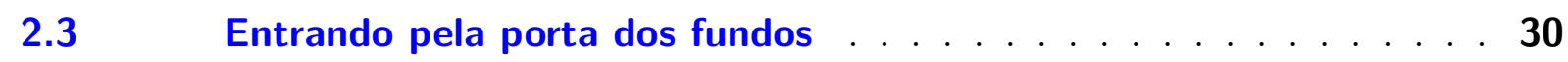

$2.4 \quad$ De olho no passado e rumo ao futuro: entre 1920 e $1930 \ldots \ldots$

2.5 Dos sonhos ao gosto amargo da desilusão: entre 1960 e 1970 . . 31

$2.6 \quad$ Na era da globalização: os cacos da história . . . . . . . . . . 32

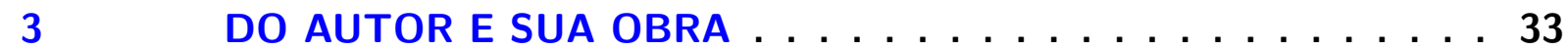

$3.1 \quad$ Os nascimentos . . . . . . . . . . . . . . . . . . 33

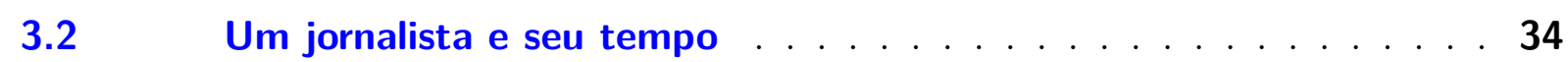

$3.3 \quad$ Ainda um jovem . . . . . . . . . . . . . . . . 35

$3.4 \quad 0$ primeiro olhar sobre a América Latina . . . . . . . . . . 35

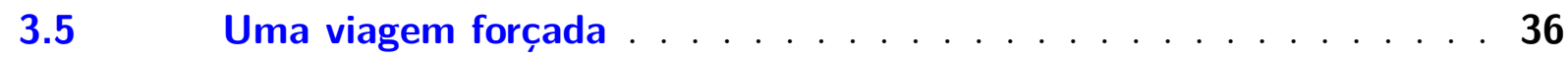

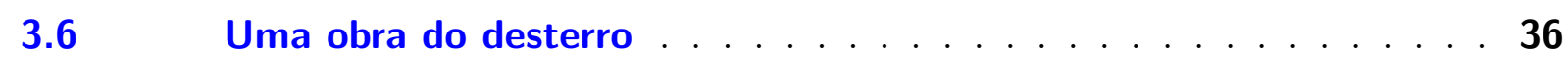

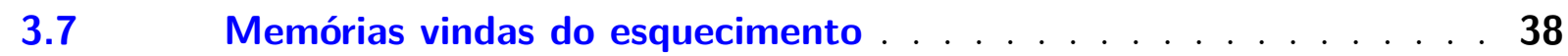

$3.8 \quad \mathrm{O}$ retorno do andarilho . . . . . . . . . . . . . . 40

4 DA OBRA A UMA REFLEXÃO SOBRE A LATINIDADE . . . . . . 41

$4.1 \quad$ Um breve prelúdio $I I \ldots \ldots \ldots \ldots \ldots \ldots$

4.2 Das semelhanças: uma pequena pausa em nosso percurso . . . . . 42

4.2 .1 Duas grandes obras do desterro . . . . . . . . . . . . . . 43

4.2.2 O suicídio e a morte. O suicídio e os nascimentos . . . . . . . . . . . 44

$4.3 \quad$ Um retorno à teoria $\ldots \ldots \ldots \ldots \ldots \ldots$ 
4.4 Eduardo Galeano: o narrador . . . . . . . . . . . . . . 46

4.5 Eduardo Galeano: o historiador . . . . . . . . . . . . . . . 47

$4.5 .1 \quad$ Da estrutura da obra . . . . . . . . . . . . . . 48

$4.6 \quad 0$ que nos diz a obra . . . . . . . . . . . . . . 49

$4.7 \quad$ Um passado esquecido . . . . . . . . . . . . . . . 49

$4.8 \quad$ Uma reconquista . . . . . . . . . . . . . . . . 50

$4.9 \quad 0$ resgate dos nomes . . . . . . . . . . . . . 51

4.10 Da resistência cultural . . . . . . . . . . . . . . . 52

4.11 Sobre as mulheres . . . . . . . . . . . . . . . . . 5 52

4.12 Da violência contra os escravos à violência contra os operários . . . 54

4.13 Da polifonia de vozes . . . . . . . . . . . . 55

$5 \quad$ CONSIDERAÇÕES FINAIS . . . . . . . . . . . 57

REFERÊNCIAS . . . . . . . . . . . . . . . 59

ANEXO A - LAS DOS AMERICAS . . . . . . . . . . 62 


\title{
1 Introdução
}

\author{
Madre y abuela Vasconia \\ Mi pueblo mezcla mil mares \\ Mi nombre indígena es rojo \\ Mi lengua es blanca, mi canto es \\ negro.
}

Taiguara

\subsection{Uma identidade social}

O presente trabalho tem como ponto de partida algumas indagações acerca da constituição, adoção e representatividade do nome América Latina, por conseguinte, do próprio sentido de nossa latinidade. Indagações advindas do reconhecimento de nossa diversidade étnica, cultural, social e histórica. Uma diversidade que se reflete na existência de diversos olhares sobre nosso objeto de estudo. E, dentre esses inúmeros olhares sobre o processo de construção de uma identidade latino-americana, escolhemos desenvolver nossas reflexões a partir da obra histórico-literária, Memória do Fogo do autor uruguaio, Eduardo Galeano. Talvez, em um primeiro momento, essa decisão possa ser bastante questionada, contudo, esperamos mostrar a correção de nossa escolha, ao respondermos de maneira satisfatória algumas questões teóricas e práticas. Questões relacionadas de forma direta e imediata à natureza de nosso objeto de estudo, uma identidade social, mais precisamente, uma identidade constituída de sociedades nacionais, agregações de sociedades nacionais (América Latina), e a sociedades ou grupos subnacionais (BETHEL, 2009, p. 19). Nesse sentido, o conteúdo histórico, presente nos fragmentos narrativos que compõem a trilogia Memória do Fogo, possibilita nosso acesso a uma diversidade de fatos e acontecimentos oriundos dos mais diversos cantos da América, em particular da América Latina.

Absorto, ausente, está el prisionero sentado a la entrada de la casa de Cristóbal Colón. Tiene grillos de hierro en los tobillos y las esposas le atrapan las muñecas.

Caonabó fue quien redujo a cenizas el fortín de Navidad, que el Almirante había levantado cuando descubrió esta isla de Haití. Incendió el fortín y mató a sus ocupantes. Y no sólo a ellos: en estos dos años largos, ha castigado a flechazos a cuantos españoles pudo encontrar en su comarca de la sierra de Cibao, por andar cazando oro y gente.

Alonso de Ojeda, veterano de las guerras contra los moros, fue a visitarlo en son de paz. Lo invitó a subir a su caballo y le puso estas esposas de metal bruñido que le atan las manos, diciéndole que ésas eran las joyas que usaban los reyes de Castilla en sus bailes y festejos. 
Ahora el cacique Caonabó pasa los días sentado junto a la puerta, con la mirada fija en la lengua de luz que al amanecer invade el piso de tierra y al atardecer, de a poquito, se retira. No mueve una pestaña cuando Colón pasa por allí. En cambio, cuando aparece Ojeda, se las arregla para pararse y saluda con una reverencia al único hombre que lo ha vencido. (GALEANO, 1991, p. 50).

Ainda sobre a natureza de nosso objeto de estudo, a dinâmica narrativa presente na obra Memória do Fogo, resultante do entrelaçamento entre a sua estrutura fragmentada e o seu conteúdo histórico, proporciona elementos para elaborarmos conjecturas sobre o processo de formação da América Latina e as transformações ocorridas na "a unidade dialética associada ao conceito de identidade, a saber o da permanência na mudança" (PAIVA, 2007, p. 77). Deixamos de ser índios para sermos hispano-americanos. Deixamos de ser hispano-americanos para sermos latino-americanos.

No caso de uma identidade social, como a latino-americana, podemos dizer que sua unidade dialética é o resultado ambivalente y dinâmico de la tensión entre elementos e interesses contrarios y comunes (RAMOS, 2012, p. 27). Tal descrição, coloca nosso objeto de estudo, também, no campo da política.

De acordo com a complexidade apresentada por nosso tema de estudo, até o presente momento, procuramos efetivar um diálogo entre uma psicologia social crítica e as demais ciências humanas. Apenas a efetivação desse diálogo proporciona condições para uma análise profunda e abrangente de nosso processo identitário, expondo seus limites e suas contradições.

Las reflexiones sobre las identidades colectivas, en particular sobre la identidad de América Latina, requieren de una perspectiva amplia que incluya dinámicas y elementos diversos y contradictorios, relaciones hegemónicas e igualitarias, necesitan de un extenso horizonte de tiempo que ponga en tensión el pasado con el futuro deseado-temido que permita visualizar el presente para darle sentido a nuestros actos y a nuestras vidas personales y colectivas. (RAMOS, 2012, p. 19)

Assim, ao seguirmos o caminho aberto por Eduardo Galeano, procuramos assinalar as contradições existentes no processo de formação da América Latina e, ao mesmo tempo, identificá-las como elementos estruturantes do nosso processo identitário. Aos vencedores o direito ao espólio.

Nesse ponto, antes de darmos continuidade a nossa breve introdução, precisamos esclarecer que não é nossa intenção encontrar ou descrever um caráter nacional ou supranacional, mas, problematizar a relação entre nossa diversidade étnica e cultural como somos nomeados. 
Nombrar un grupo humano es darle existencia atribuyéndole características y delimitando su especificidad según los parámetros ideológicosculturales prevalecientes de la época y las relaciones de poder del momento histórico de dicho acto nominativo (RAMOS, 2012, p. 17)

Na tentativa de obtermos uma maior clareza em nossa exposição, a partir de agora, dividiremos nossa introdução em duas partes. Na primeira parte, apresentaremos algumas justificativas histórico-literárias para nosso método de análise. Na segunda parte apresentaremos as bases teóricas para nossas reflexões.

\subsection{Uma justificativa literária}

Sob um ponto de vista histórico-literário, nossa abordagem sobre a identidade latino-americana, encontra respaldo na existência de uma característica bastante peculiar ao processo de formação da América. Podemos definir essa peculiaridade do continente americano como sendo, a estreita relação entre a formação das diversas literaturas regionais e a formação de suas respectivas nacionalidades. Uma contribuição bastante importante e profunda como assinalada por Ureña (1949) apud Perrone-Moisés (1997), através da "constituição de uma consciência nacional e, assim, na construção das próprias nações latino-americanas. Não é por acaso que a lista de presidentes latino-americanas que foram escritores é longa". Entretanto, essa relação mais próxima entre o ativismo político e a literatura é mais forte na América Latina, pois, "apesar de paralelos significativos, os escritores norte-americanos que estavam fundando uma literatura nacional pareciam ter uma postura metapolítica, uma crítica aparentemente desinteressada, que era rara no hemisfério sul (SOMMER, 2004, p. 19). Uma relação que, de fato, se mostra um tanto quanto complicada, pois os autores "latino-americanas demonstravam estar mais integrados às lutas partidárias e menos disponíveis para fazer crítica social transcendente" (SOMMER, 2004, p. 19). Contudo, de um modo geral, no processo de formação da América, podemos salientar, a importância da literatura na construção de uma passado em uma região destituída de sua história. Seja em virtude da distância entre as colônias e suas respectivas metrópoles, seja em virtude da aniquilação e destruição cultural dos povos originários.

Outro fator de complicação decorrente dessa necessidade de se desenvolver à imagem e semelhança do Outro, num lugar desprovido do passado do outro e despojado do seu próprio passado, foi a dupla missão de que se sentiram investidos os primeiros escritores latino-americanos: a missão de criar, ao mesmo tempo, uma pátria e uma literatura. Candido (1969) apud Perrone-Moisés (1997).

Continuando dentro dos limites da relação entre literatura e identidade latinoamericana, precisamos assinalar, segundo Ardão (1980) apud Farret e Pinto (2011), a 
grande e decisiva influência do poema Las dos Américas ${ }^{1}$, do escritor e jornalista, José Maria Torres Caicedo, publicado em 1858, em Paris, como o momento de consolidação da ideia e do nome América Latina.

Apesar da estreita relação entre a nascente literatura regional e a constituição de culturas nacionais favorecerem a defesa de nosso método de análise, não podemos deixar de assinalar alguns graves problemas relacionadas a essas obras fundadoras. Muitas dessas obras nacionais e nacionalistas apresentavam um acentuado caráter ideológico e naturalizador das relações sociais. Esse caráter ideológico é exaustivamente analisado por Dante Moreira Leite (2002), apontando-o como elemento central na construção de discursos de superioridade racial e social, justificando a dominação de uma nação sobre a outra ou de uma classe social sobre a outra. Esse componente racial e naturalizador pode ser observado, por exemplo, ao longo do poema Las dos América, ao estabelecer, mais do que uma disputa, uma divisória entre a a raça latina e a raça anglo-saxônica. O caráter ideológico encontrado nesses romances servia, também, para ocultar as diferenças e as mazelas sociais em nome de um projeto nacional.

No caso específico dos romances 'históricos' latino-americanos do século XIX, as inseguranças irritantes que a escrita produz apenas conseguem espreitar através das inscrições mais patentes e assertivas. As tensões existem, não há dúvidas, e elas geram grande parte do interesse na leitura do que, caso contrário, seria um cânone opressivamente padronizado. Mas o que quero dizer é que aquelas próprias tensões não poderiam ser apreciadas se a energia espantosa dos livros não estivesse sendo canalizada para negá-las (SOMMER, 2004, p. 25)

A relação literatura e política corrobora a natureza política de nosso objeto de estudo, remetendo-o ao campo da disputa política, isto é, das relações de poder configuradas desde a chegada dos europeus ao Novo Mundo. Disputas políticas que reverberam de forma direta no discurso sobre nosso processo identitário. Aos vencedores o direito à palavra, aos vencidos um silêncio de morte. Nesse sentido, Memória do Fogo, propicia um acesso a história da América Latina através de uma prisma diferente da historiografia oficial.

Ojalá Memoria del fuego pueda ayudar a devolver a la historia el aliento, la libertad y la palabra. A lo largo de los siglos, América Latina no sólo ha sufrido el despojo del oro y de la plata, del salitre y del caucho, del cobre y del petróleo: también ha sufrido la usurpación de la memoria. Desde temprano ha sido condenada a la amnesia por quienes le han impedido ser. La historia oficial latinoamericana se reduce a un desfile militar de próceres con uniformes recién salidos de la tintorería. Yo no soy historiador. Soy un escritor que quisiera contribuir al rescate de la memoria secuestrada de toda América, pero sobre todo de América Latina, tierra despreciada y entrañable: quisiera conversar con ella,

$1 \quad$ Anexo A 
compartirle los secretos, preguntarle de qué diversos barros fue nacida, de qué actos de amor y violaciones viene. (GALEANO, 1991, p. XII)

Um esquecimento impresso no próprio nome América Latina, fruto do ocultamento das demais culturas formadoras de nossa identidade, seja dos habitantes originários, seja dos escravos africanos, em detrimento da europeia, mais precisamente a cultura latina. Ocultamento também representado no início tardio de estudos sociológicos ou antropológicos sobre a importância e a influência da cultura "indígena"ou africana na construção de uma identidade nacional. Segundo Ureñas (2001), somente no final da segunda década do século XX, que se iniciam os primeiros estudos sobre a importância da cultura dos povos originários na conformação de uma civilização hispano-americana. Interessante notar que, nessa mesma obra, há um reconhecimento da importância das culturas "indígenas"visível através da dedicação de um capítulo exclusivo ao tema. Contudo, o mesmo reconhecimento não é dado à influência da cultura africana. Mesmo hoje, quando a ideia de uma América Latina apresente-se mais "diversidad, la complejidad y el carácter asimétrico y contradictorio de nuestras culturas van ocupando um lugar más importante en las reflexiones sobre la identidad latinoamericana" (RAMOS, 2012, p. 23), não podemos esquecer sua origem elitista e conservadora. Hay momentos históricos cruciales para la formación de la identidad latinoamericana, pero esto no significa que ella se haya formado de una vez para siempre o que haya sido concebida de igual forma por los diversos grupos de la sociedad(LARRAÍN, 1994, p. 33)

Mesmo que não possamos classificar a trilogia Memória do Fogo com uma obra fundadora (SOMMER, 2004), vários aspectos de sua composição oferecem elementos para uma compreensão de nossa identidade. De certo modo são os mesmo aspectos que a tornam uma obra de difícil classificação. "Se trata de una obra de difícil classificación, en tanto tiene rasgos de história, de la crónica novelada, de la narración, del estilo poético $y$ del poema em prosa"(RIVA, 1996, p. 54). Ao nosso entender, a dificuldade para ser categorizada, transparece uma de suas principais virtudes. Em uma época em que tudo é rotulado e homogeneizado, a impossibilidade de receber uma classificação aponta para o trabalho criativo, por isso mesmo, ativo do autor. Em uma época, também, onde as bases para a constituição de uma narração tradicional foram destruídas, só resta ao grande escritor e buscar novos caminhos para a construção outras formas narrativas (BENJAMIN, 1994), eis aqui a grande virtude de "Eduardo Galeano"

\subsection{Uma justificativa teórica}

Ao conduzirmos nossa reflexão acerca da identidade latino-americana, através da vereda histórico-literária aberta por Eduardo Galeano em Memória do Fogo, expressamos nosso aceite de dois supostos convites. O primeiro, da necessidade de repensarmos e 
reescrevermos a história da América Latina. Convite feito pelo próprio Eduardo Galeano, através da construção de uma narrativa repleta de pausas e silêncios, resultante de sua construção fragmentada e justaposta. Um estrutura narrativa com um objetivo bastante claro, "para que la historia respire y el lector la sienta viva, el autor ha recreado a su manera los datos disponibles de cada episodio; pero tanto los mitos como las viñetas históricas han sido elaboradas sobre una base documental rigurosa" (GALEANO, 1991, p. XII). O segundo, realizado por Walter Benjamin, ao apresentar "explicitamente, e sob aspectos diversos, a questão do nome próprio, interrogando-se sobre a sua substancialidade ou a sua natureza acidental, sobre a relação entre o 'ser' e o 'chamar-se', enfim sobre o mistério do nome próprio" (BARRENTO, 2013, p. 9). De uma maneira mais precisa e seguindo as indagações abertas por Galeano e Benjamin, nossas reflexões sobre a identidade latinoamericana se direcionam a relação entre o ser e aquilo que o designa.

Serei eu aquele que se chama W. B., ou chamo-me simplesmente W. B.? São duas faces da mesma moeda, mas a segunda está desgastada, e a primeira é que tem o brilho da cunhagem original. Esta primeira versão torna evidente que o nome é objeto de uma mimese. Sem dúvida que é próprio da sua natureza singular mostra-se, não naquilo que virá, mas sempre e apenas naquilo que já foi, que o mesmo é dizer, no que já foi vivido. O hábito de uma vida vivida: é isso que o nome guarda e também evidência. Para além disso, o conceito de mimese já diz que o domínio do nome é do semelhante. E como a semelhança é o organon da experiência, isso significa que o nome só pode ser reconhecido em contextos de experiência. Só neles a sua essência, que é uma essência de linguagem poderá ser identificada (BENJAMIN, 2006, p. 949).

O pequeno, mas denso fragmento filosófico citado acima, além de apresentar algumas das principais questões de Walter Benjamin acerca da relação entre o ser e o nome, define, ao mesmo tempo, os principais elementos de nossa reflexão sobre a identidade latino-americana ao estabelecer uma articulação entre a memória e a constituição de uma identidade. De outro lado, ao apontar como característica elementar do nome, a sua manifestação naquilo que já foi vivido, Benjamin, confirma a necessidade de voltarmos nosso olhar para o processo de formação e adoção do nome América Latina para compreendermos sua conformação atual.

Ao direcionarmos nossa reflexão para o campo da narrativa histórica somos conduzidos ao domínio da experiência e, ao mesmo tempo, segundo Jeanne-Marie (1994b), nos inserimos no centro de um dos grandes paradoxos da filosofia benjaminiana. De um lado, sua descrição quase melancólica do final da narrativa tradicional, presente no ensaio sobre o narrador. Do outro lado, a importância em reconhecermos esse fato e não ficarmos presos a formas antigas e mortas de narrativas, mas nos esforçarmos na criação de formas alternativas. 
Um paradoxo que, ao nosso entender, permite justificarmos definitivamente a escolha de nosso objeto de estudo, tanto estética como teoricamente. Benjamin (1994), sugere como forma de superação desse impasse a produção de outras formas narrativas que possibilitem uma experiência coletiva renovada, não uma experiência individualizada. Objetivo esse, materializado por Eduardo Galeano ao construir um história da América a partir da justaposição de pequenos fragmentos narrativos. Fragmentos compreensíveis em si mesmo mas que ao serem justapostos com outros fragmentos, também compreensíveis em si mesmo, compõem um todo muito maior e, também, compreensivo.

Retornando aos limites da relação entre identidade e memória, Jeanne-Marie (1994a), ao analisar e desenvolver o pensamento benjaminiano sobre a filosofia da história e a teoria literária, apresenta de forma bastante clara como memória e esquecimento se constituem na tecitura e na urdidura do processo narrativo.

\begin{abstract}
Hoje ainda, literatura e história enraízam-se no cuidado com o lembrar, seja para tentar reconstruir uma passado que nos escapa, seja para 'resguardar alguma coisa da morte' (Gide) dentro de nossa frágil existência humana. Se podemos assim, ler as histórias que a humanidade se conta a si mesma, como fluxo constitutivo de memória e, portanto, de sua identidade, nem por isso o próprio movimento de narração deixa de ser atravessado de maneira geralmente mais subterrânea, pelo refluxo do esquecimento que seria não só uma falha, um 'branco' de memória, mas também uma atividade que apaga, renuncia, recorta, opõe ao infinito da memória, a finitude necessária da morte e a inscreve no âmago da narração (GAGNEBIN, 1994a, p. 3)
\end{abstract}

Nesse sentido, o resgate histórico empreendido por Eduardo Galeano ganha maior importância, enquanto, ao perseguir rastros do passado, retira uma parte de nossa história do reino do esquecimento. Um resgate feito a partir de escombros e traços de um discurso.

Por fim, nossa aproximação da filosofia da história e da teoria literária benjaminiana, possibilita estabelecermos um paralelo entre a "unidade dialética permanência na mudança" da identidade e a relação entre a memória e o esquecimento inerentes a qualquer narrativa, remete nossas reflexões acerca da constituição da identidade latinoamericana para regiões limites de nosso objeto. Limite entre o que permanece e o que muda. Limite entre o recordado e o esquecido.

Buscando uma melhor contextualização de nosso objeto de estudo, no segundo capítulo, dos olhares sobre a América Latina, iremos oferecer uma breve história da constituição do nome América Latina em paralelo ao processo de formação continental. No terceiro capítulo, do autor a sua obra, apresentaremos uma breve biografia de Eduardo Galeano, além de tecermos algumas considerações sobre sua obra. No quarto capítulo, da 
obra à latinidade, desenvolveremos nossa reflexão sobre a identidade latino-americana a partir da Memória do Fogo. No quinto e último, apresentamos nossas conclusões finais... 


\title{
2 Dos olhares sobre a América Latina
}

\author{
Coração americano \\ Acordei de um sonho estranho \\ Um gosto, vidro e corte \\ Um sabor de chocolate \\ No corpo e na cidade \\ Um sabor de vida e morte
}

Fernando Brant e Milton Nascimento

\subsection{Um breve prelúdio}

Nesse capítulo, enquanto apresentamos de maneira bem sucinta a relação entre a história de formação do nosso continente e o processo de formulação e adoção do nome América Latina, apontamos também, quando possível, o movimento de "usurpação da memória" mencionado por "Eduardo Galeano" (1991). Na verdade, processos de "usurpação da memória", da destruição de monumentos à descaracterização religiosa de deidades.

\footnotetext{
De pronto, de golpe, acaban los gritos y los tambores. Hombres y dioses han sido derrotados. Muertos los dioses, ha muerto el tiempo. Muertos los hombres, la ciudad ha muerto. Ha muerto en su ley esta ciudad guerrera, la de los sauces blancos y los blancos juncos. Ya no vendrán a rendirle tributo, en las barcas a través de la niebla, los príncipes vencidos de todas las comarcas.

Reina un silencio que aturde. Y llueve. El cielo relampaguea y truena y durante toda la noche llueve.

Se apila el oro en grandes cestas. Oro de los escudos y de las insignias de guerra, oro de las máscaras de los dioses, colgajos de labios y de orejas, lunetas, dijes. Se pesa el oro y se cotizan los prisioneros. De un pobre es el precio, apenas, dos puñados de maíz. Los soldados arman ruedas de dados y naipes.

El fuego va quemando las plantas de los pies del emperador Cuauhtémoc, untadas de aceite, mientras el mundo esté callado y llueve.(GALEANO, 1991, p. 67)
}

\subsection{Para contextualizar o problema}

Ao voltarmos nossa atenção para o processo histórico de constituição de nossa atual identidade latino-americana, compreendemos sua abrangência e complexidade. Uma complexidade desvelada na grande diversidade de conceitos e suas respectivas justificativas, "parte de este mismo processo histórico de autoconstituición son las controversias teóricas a cerca de la identidad latinoamericana" (LARRAÍN, 1994, p. 33). Dentre as muitas controvérsias destacamos aquelas relacionadas à origem do nome América Latina até as 
indagações sobre quais seriam os elementos culturais determinantes na construção de nossa identidade.

\begin{abstract}
Houve, certamente, latino-americanos - pensadores individuais e, ocasionalmente, uma "geração"nacional - que deram contribuições significativas para a elaboração de um programa adequado a seu país ou seu continente. O problema era que, muitas vezes, ficavam confusos quando tinha de identificar os ingredientes domésticos que deviam ser absorvidos e adaptados. O grande exemplo clássico é Domingo Faustino Sarmiento (Argentina 1811-1888), cujas reflexões sobre a vida e a época do caudillo argentino Facundo, em Civilización y barbarie (1845), pareciam opor a Europa liberal, tal como era divulgada em Buenos Aires, à "barbárie"dos pampas (MORSE, 2009, p. 24).
\end{abstract}

Contudo, apesar das muitas controvérsias, parece haver um forte consenso sobre a necessidade de retornarmos ao período colonial na tentativa de uma melhor compreensão de nosso processo identitário.

Ao refletir sobre as raízes da América Latina, forçosamente teremos de transitar por caminhos que nos remeterão a vários passados históricos distintos que se confrontam cotidianamente nas mais diferentes formas de relação. Teremos de varrer todo o período colonial, testemunha de de tantos encontros e desencontros com nosso passado, de nossas buscas e desprezo por todos eles. (AZEVEDO, 1996, p. 19)

Entretanto, as semelhanças ficam circunscritas a esse ponto. A partir desse ponto em comum, surgem diferenças epistemológicas e teóricas. Do objetivo à justificativa para esse retorno. Das implicações e alcance dos fenômenos e acontecimentos desse período. Para Larraín (1994), por exemplo, direcionar seu olhar sobre o período colonial significa ir ao encontro do primeiro momento gerador de uma crise identitária em nossa história. Esses momentos despertariam um maior interesse tanto teórico como prático sobre o tema identitário.

Para que la identidad llegue a ser una pregunta importante, parece requerirse un período de crisis e inestabilidad, una amenaza al modo de vida tradicional, especialmente si esto sucede en presencia de otras formas culturales. (LARRAIN, 1994, p. 33)

Crises geradas pelo desequilíbrio entre culturas diversas quando de seu encontro ou relacionamento ou, ainda, geradas em momentos de transição sócio-cultural. Mais uma vez, temos marcado o caráter dinâmico e político do processo de adoção de uma identidade social.

En cualquier encuentro asimétrico y conflictivo entre dos culturas, sea porque una invade y coloniza la otra, sea porque a través de medios extensivos de comunicación y comercio, entran en relación estrecha, surge 
la problemática de la identidad cultural. La pregunta por la identidad cultural no emerge normalmente en situaciones de relativo aislamiento, prosperidad y estabilidad. (LARRAÍN, 1994, p. 33).

Entretanto, para Francisca Azevedo (1996), o período colonial marca de forma indelével o nosso ser. Marca originada a partir do encontro (choque) entre a diversidade cultural dos povos originários com a cultura europeia, expressa em nosso eterno estranhamento.

\begin{abstract}
Ainda hoje não temos idéia de quem somos, caminhamos lado a lado, nos esbarramos nos percalços da história, mas continuamos desconhecidos e vivemos no conflituoso embate dialético de não sermos índios, não sermos negros, não sermos brancos, sendo todos ao mesmo tempo (AZEVEDO, 1996, p. 19)
\end{abstract}

\title{
2.2.1 Outros momentos de crise
}

Larraín (1994) aponta, além do encontro inicial entre a cultura espanhola e as diversas culturas dos povos originários quando do descobrimento do novo mundo, a existência de outros três momentos de crise nos quais a pergunta sobre nossa identidade ganha destaque e relevo. O segundo momento de crise seria gerado pelos diversos movimentos de independência e a consolidação dos estados nacionais. Movimentos influenciados pelos ideais iluminista e positivista.

Un segundo momento importante en que re-emergen las preguntas sobre la identidad es la crisis de la independencia y el período de constitución de los estados nacionales a comienzos del siglo XIX. El impacto de la Ilustración y el pensamiento racionalista adquieren una enorme importancia en las nuevas definiciones (LARRAÍN, 1994, p. 34).

O terceiro seria o período entre 1914 e 1930. Período de grandes transformações tanto na América como na Europa. Na América, la dominación oligárquica de los terratenientes latinoamericanos empieza a deteriorarse, y las clases medias y obreras recientemente movilizadas comienzan a desafiar el orden estabelecida. (LARRAÍN, 1994, p. 34) Ao mesmo tempo, toda a efervescência política e cultural vividas pela Europa, permite o surgimento de questionamentos sobre os modelos culturais e sociais aqui difundidos e, por conseguinte, da concepção de nossa identidade.

Em sua fase áurea (1910-1930), o modernismo, sobretudo a partir de sua arena parisiense, acabou por causar impacto sobre a América Latina, mas não como um mero papel de tutor. É que na época a Europa sofria de uma crise de nervos associada com a tecnificação, a comoditização, a alienação e a crescente violência, tal como eram expressas nas contradições marxistas, na decadência spengleriana, nas invasões freudianas do subconsciente e, é claro, na industrialização e na Primeira 
Guerra Mundial. Esse aparente colapso dos pressupostos evolutivos animou os latino-americanos a desdenhar os pressumíveis determinismos de seu passado e a inventar uma nova 'realidade' e um novo futuro. Agora a Europa não oferecia modelos, mas patologias. O desencanto no centro deu ensejo à reabilitação na periferia. (MORSE, 2009, p. 27)

O quarto e último período de crise identitária assinalado por Larraín (1994), situase no final dos anos 60 e início dos anos 70. Período marcado pelo fracaso de los regímenes populistas, el progresivo estancamiento industrial y la creciente radicalización de las clases populares condujeron a una serie de golpes militares en varios países del cono sur. Esto suscita una vez más nuevas preguntas sobre nuestra identidad. (LARRAÍN, 1994, p. 34)

Apesar de nossa concordância com Larraín (1994) sobre a ocorrência, ao longo de nossa história, desses quatro importantes momentos em que a reflexão sobre a questão identitária ganha relevo, precisamos, assim como faz Ramos (2012), acrescentar a existência de um quinto momento de crise identitária. Um momento em que todas as formas de identidades parecem ser questionadas, das individuais às sociais.

\begin{abstract}
En la coyuntura actual, la identidad latinoamericana, como todas las otras, está interpelada principalmente, pero no exclusivamente, por un sistema que globaliza excluyendo (especie de 'apartheid' local-global), integra 'desestructurando' (algo como un 'integreid' local-global) y pretende imponer un esquema simplista basado en relaciones utilitaristas, mercantilistas y de competición a ultranza. ¡Todo lo contrario de una propuesta civilizacional! (RAMOS, 2012, p. 19).
\end{abstract}

Assim, a reflexão, nesse momento sobre a constituição de identidades locais, principalmente a latino-americana, segundo Ramos (2012), ganham importância e valor estratégico, por fornecerem um contra-ponto ao discurso de globalização, um discurso hegemônico e excludente. Nesse sentido, discutir uma identidade latino-americana é inseri-la

\footnotetext{
actualmente dentro de la pugna entre una globalización de horizonte cerrado, unidimensional y otra mundialización alternativa, que está en sus primeros pasos, de horizonte abierto y plural en donde se conjugan la diversidad y todos los posibles con sus luces y sus sombras que necesariamente tienen todos los procesos sociales sean estos locales o globales (RAMOS, 2012, p. 18).
}

Contudo, ao nosso entender, o atual momento, possibilita, também um questionamento da própria essência dessa identidade latino-americana. Segundo Lisboa (2014), dois fatores se conjugam e se entrelaçam no processo de enfraquecimento do sentido de uma identidade latino-americana. O primeiro, do campo da política internacional, isto é, a perda da hegemônia norte-americana na região, a partir da escolha do governo brasileiro em priorizar suas relações como seus parceiros da América do Sul, tendo como resultado a criação do Mercosul e, posteriormente, a criação da Unasul - com intensa participação 
dos governos de Argentina e Venezuela. O segundo, do campo das sociedades civis e suas demandas.

Já do lado da sociedade civil, temos a simultânea ascensão dos movimentos populares, particularmente o indígena, negro e das mulheres, com clara opção descolonial. A emergência das indianidades e africanidades torna insustentável definir o subcontinente pela latinidade dos descendentes de europeus. Como tanto o termo América Latina quanto os atuais Estados nacionais não expressam a rica diversidade de culturas aqui presentes, surge um questionamento do Estado mono-nacional e a afirmação do Estado pluri-nacional (LISBOA, 2014, p. 515).

Para entendemos melhor todo esse processo histórico, analisaremos, agora, cada um desses momentos de crise com seus significados e suas consequências.

\title{
2.2.2 O nascimento: um instante entre a vida e a morte
}

\author{
Danem-se, eu não sou um índio, sou \\ um aymara. Mas você me fez um \\ índio e como índio lutarei pela \\ libertação.
}

Fausto Reinaga

Apesar de nossa compreensão sobre o processo identitário latino-americano, ser resultante do próprio processo de formação e constituição do continente, não podemos deixar de sublinhar alguns traços ou aspectos que parecem se perpetuar, seja em si mesmos ou em seus desdobramentos. No caso do período colonial, ao nosso entender, seu traço mais marcante é a maneira como os colonizadores europeus levam a cabo, no primeiro momento, a negação dos povos originários, para, em um segundo momento, estende-lo aos escravos e aos mestiços.

Os milhares de povos originais (carijós, caigangs, aymaras, tojolabales...) foram orientalizados como índios, enganosa alegoria que advém do equívoco de onde Colombo pensa ter chegado. Este roubo de nomes próprios e a dissolvição das infinitas nuanças e consequente homogeneização identitária foi um passo fundamental na destruição das formas de conhecimento e da cosmovisão dos colonizados. Este despojamento também ocorreu com a população trazida da África, submetida à mesma identidade colonial e racial: negros (LISBOA, 2014, p. 503).

O nascimento das "Índias Ocidentais", expressam de forma nítida e aparente o desaparecimento ou o encobrimento de outras Terras, outros Mundos.

Antes de 1492, América no figuraba en ningún mapa, ni siquiera en el de los pueblos que vivían en el valle de Anáhuac (território azteca) y 
Tawantinsuyu (território inca). Los españoles y los portugueses, únicos ocupantes europeos durante el siglo XVI, bautizaron el continente cuyo o control y posesión estaban en sus manos. Hoy en día resulta difícil pensar que no los incas e los aztecas no vivíam em América y más aún que no vivián en América Latina (MIGNOLO, 200\%, p. 28).

Há divergências sobre o porquê do tratamento tão desumano dispensado pelos europeus aos povos originários e, posteriormente, aos escravos africanos. Larraín (1994) apud Todorov (2003), aponta como principal motivo desse tratamento o atraso cultural da região ibérica, em particular da Espanha, para a compreensão dos atos de violência cometidos pelos colonizadores.

La cultura ibérica en 1492 no era propiamente moderna y racionalista, sino que estaba profundamente influenciada por la religión, los valores morales absolutos y la intolerancia contra cualquier cosa diferente. España era todavía un país semifeudal. Dada la estrechez e intolerancia de la cultura española de ese tiempo no es sorprendente que los conquistadores quisieran imponer sus ideas desde el principio y sin mayores consideraciones. No podían sino mirar a los indios a través de su estrecho prisma cultural (LARRAÍN, 1994, p. 34).

De um outro lado, Dussel (1994) aponta como justificativa para todas as formas de violência a que os povos originários e, posteriormente, os escravos vindos da África foram submetidos, ao início do Mito da Modernidade e, por conseguinte, de um conhecimento eurocêntrico.

La Modernidad se originó en las ciudades europeas medievales, libres, centros de enorme creatividad. Pero 'nació' cuando Europa pudo confrontarse con 'el Otro' y controlarlo, vencerlo, violentarlo; cuando pudo definirse como un 'ego' descubridor, conquistador, colonizador de la Alteridad constitutiva de la misma Modernidad. De todas maneras, ese Otro no fue 'descubierto' como Otro, sino que fue 'encubierto' como 'lo Mismo' que Europa ya era desde siempre. De manera que 1492 será el momento del 'nacimiento' de la Modernidad como concepto, el momento concreto del 'origen' de un 'mito' de violencia sacrificial muy particular y, al mismo tiempo, un proceso de 'encubrimiento' de lo no-europeo (DUSSEL, 1994, p. 8).

Não é nossa intenção, aqui, determinar de maneira definitiva quais os elementos culturais presentes na região ibérica justificariam as ações dos colonizadores no Novo Mundo, mas, apresentar a existência de outras justificativas além da busca pelo ouro e pelo poder. O mais importante para nós, são as consequências humanas e históricas. De um lado, vemos a extinção de populações inteiras junto com suas culturas. Do outro lado, a constituição de mecanismos de defesa, tanto real como simbólica. Dos levantes indiginas às rebeliões dos escravos. 
La verdad es que, como una forma de resistencia, los indios cubrieron sus propias formas culturales y religiosas con un barniz de religión católica aceptable a los españoles, y los ritos eran especialmente adecuados para ese propósito. Por eso algunos comentaristas han observado que el catolicismo que se expandió con la conquista fue más bien nominal, externo y cúltico y no implicó una conversión profunda. Este es un rasgo que habría sobrevivido hasta hoy (LARRAÍN, 1994, p. 39)

Entretanto, cabe ressaltar que esse olhar e prática desumanizadores apesar de hegemônico, não correspondia a uma unanimidade. "Ainda no século XVI, Las Casas e Montaigne denunciaram o quanto a humanidade empobreceu com este epistemicídiogenocídio.” (LISBOA, 2014, p. 503)

Desse contado entre as culturas europeias e as culturas dos povos originários e depois dos escravos vindos da África, observamos a construção de um olhar moldado a partir de um sentimento de superioridade da cultura europeia sobre as demais. Ao mesmo tempo, observamos um cultura intensamente influenciada e determinada pela religião católica, por isso, refratária ao conhecimento científico e a ilustração.

Del encuentro original entre la cultura española y las culturas indígenas emergió un nuevo modelo cultural, fuertemente influenciado por la religión católica, intimamente relacionado con el autoritarismo político y no muy abierto a la razón científica. Este modelo coexistió fácilmente con la esclavitud, el racismo, la inquisición y el monopolio religioso. La Iglesia rápidamente se convirtió en una institución poderosa y rica. En los primeros 100 años, la Iglesia había adquirido 70.000 iglesias, 200 conventos y en muchos países poseía cerca de la mitad de la tierra disponible (LARRAÍN, 1994, p. 40).

O desdobramento dessa conformação cultural, não poderia ser outra, o desenvolvimento de estratégias de resistência pelos deserdados da terra, como o já mencionado, e a constituição de um cultura mutilada e inferiorizada.

Cultura surgida de la unión, pero no asimilación, de la cultura propia de esos hombres. Cultura de expresiones encontradas y que, por serlo, lejos de mestizarse, de asimilarse, se han yuxtapuesto. Yuxtaposición de los supuestamente superior sobre lo que se considera inferior. La misma relación que guardarán, entre si europeos y americanos, relación de señores y siervos, conquistadores y conquistados, colonizados y colonizadores. Relación que el mestizo, tanto cultural como racialmente, se transforma en conflicto interno. Conflicto de hombre que lleva en su sangre y cultura al dominador y al bastardo. Bastardía que le viene al americano, no sólo por la sangre, sino también por la cultura, o simplemente por haber nacido en América y no en Europa. (ZEA; LATINA, $1978, p .5)$

Uma contradição que permanece e se expressa no período subsequente às guerras de independência e consolidação dos estados-nações, como um olhar depreciativo sobre si 
mesmo, ou, ao menos, sobre uma parte de si, marcadamente a indígena a africana e todas as formas de mestiçagens, desdobrando-se na defesa de um branqueamento da sociedade em nome do progresso.

Façamos uma pequena pausa para analisarmos os nomes designados ao novo continente.

\subsubsection{Das Índias Ocidentais à América: sob o domínio do Outro}

Como já destacado, a (re)nomeação da terra recém encontrada, mostram o desrespeito e o processo de negação sofrido pelos povos originários a partir da invasão europeia. Ao mesmo tempo, essa (re)nomeação, marca de forma indiscutível a domada de posse pelos europeus do novo continente.

Negar os nomes existentes e atribuir novos foi decisivo para a colonização mental dos nativos. Como a linguagem, ao invés de algo cosmético e superficial, é uma estrutura profunda, subjugá-la é central no processo de dominação (LISBOA, 2014, p. 502).

Se a ação de (re)nomear expressa a posse sobre as terras recém encontradas, a escolha dos nomes também não é neutra, cada uma guarda a expressão do olhar do colonizador sobre sua posse.

Segundo Todorov (2003), o erro cometido por Colombo, ao batizar sua descoberta como Índias Ocidentais e, mesmo com todos os indícios em contrário, manter sua designação, expressa o processo de negação do Outro que acompanha todo o período de colonização. O nome Novo Mundo expressa a força da religião católica, pois, faz menção a possibilidade da construção de um cristianismo renovado e sem pecados, enquanto marca a imaturidade de seus habitantes e a necessidade de conduzi-los ao caminho da verdadeira fé.

Por fim, o nome América, homengem a Américo Vespúcio, guarda com as demais denominações, a ação ativa e dominadora do colonizador europeu.

Ao inventarem estes nomes, os europeus, além de eliminar as denominações originais dos povos que aqui viviam há milênios e ocultar toda alteridade, faziam uma projeção de si próprios, representando o novo mundo como um continuum da Europa. Não há uma descoberta da América. Esta nasce ontologicamente sob o signo do encobrimento, da negação do Outro, da ocultação da miríade de outridades aqui presentes (LISBOA, 2014, p. 503).

Sentimentos de superioridade europeia e inferioridade americana que parece perduraram ainda hoje. Aqui, nada funciona. Tudo está errado, não é como na França. 


\subsubsection{Da independência à consolidação dos Estados-Nações}

Os movimentos de independência colocam em xeque o antigo padrão cultural, marcado pela forte influência religiosa, se caracterizando pela defesa de um estado laico e, ao questionar o pacto colonial, defendendo o livre comércio. Entretanto, em virtude da manutenção de um olhar depreciativo sobre si mesmo, durante o processo de consolidação dos estados-nações, surgem contradições que de algum modo são atualizações dos preconceitos criados no esteio do período colonial. Entre uma de suas bandeiras, defendem o fim da escravatura, ação condizente com os valores iluministas e liberais, contudo, ao mesmo tempo, renegam a importância da diversidade na constituição de nossa cultura e defendem, através da imigração de europeus, um rápido branqueamento da sociedade.

A fines del siglo XIX la influencia del positivismo y otras ideas iluministas estaba en su cénit. Estas posiciones frecuentemente asumieron formas bastante radicales de autocrítica. Tendían a rechazar el legado cultural indoibérico, resultado de tres siglos de colonización, y ponían sus esperanzas en que soluciones europeas o norteamericanas pudieran implementarse para compensar las inherentes deficiencias latinoamericanas. En muchos casos la descripción de esas deficiencias tenía connotaciones claramente racistas. América Latina tenía que ser civilizada y sus rasgos culturales atrasados y bárbaros erradicados (LARRAÍN, 1994, p. 41).

As elites criollas ao incorporarem as ideias vindas da Europa de maneira acrítica, assumem, também, ideias estereotipadas e preconceituosas. A sempre algo para indicar como causa de nosso atraso e inviabilidade social.

Esto demuestra que en gran medida el consumo de los valores europeos
por los intelectuales ilustrados latinoamericanos fue más bien acrítico,
hasta el punto que incluso las connotaciones racistas fueron asimila-
das sin protesta. Esta total rendición cultural se muestra muy bien en
el famoso dicho de Alberdi: 'En América todo lo que no es europeo es
bárbaro'. Tales teorías son claramente ideológicas: ocultan las contradic-
ciones reales de las nuevas repúblicas enfatizando factores raciales como
responsables por el atraso de América Latina (LARRAÍN, 1994, p. 44).

Cabe ressaltar que o discurso de superioridade da raça pura europeia que sustenta a ideia de branqueamento, necessário à purificação da raça latino-americana, em outras palavras, eugenia, criaria, naturalmente, condições para uma elevação dos padrões culturais da região, contradiz sua própria origem miscigenada, resultado da constituição dos povos europeus - não é outro o caso, por exemplo dos povos ibéricos, anglo-saxão e francês - desde a desintegração do império romano. 
el mestizaje asuntivo que fuera propio de la cultura europea. El mestizaje que Hegel resumirá en la palabra Aufhebung, y que aparecerá como extraña al mestizaje surgido en esta América, tanto racial como cultural. La cultura europea es una cultura mestiza. Cultura asuntiva de las expresiones culturales de los múltiples pueblos y razas que empujándose, las unas a las otras, se acrisolaron a lo largo de las diversas regiones que formaran Europa. Acrisolamiento que permitió el surgimiento de culturas síntesis, como la grecoromana, a su vez asumida por la cristiana hasta culminar en la cultura europea u occidental. La cultura que se expanderá sobre el resto del planeta (ZEA; LATINA, 1978, ps. 7-8).

O encontro de culturas é expressão do universo humano, a sua mescla acontece quando da invasão de um povo sobre outro ou quando da realização de comércio e comunicação (Larraín, 1994). Se ocorre uma negação de início, com o passar do tempo, ela acontecerá fatalmente. No fundo as culturas são mestiças, salvo quando em isolamento. As ideias negativas sobre a mestiçagem, no caso da América Latina, refletem uma visão de superioridade de uma classe sobre as demais, servindo como justificativa para a manutenção do status quo, sendo, possível sua confrontação, apenas quando de uma maior organização das classes popular e trabalhadora. O que acontece tardiamente, em decorrência do atraso da chegada dos ideais socialistas e anarquistas presentes na Europa já no século XIX.

\subsubsection{Da Hispanoamérica à América Latina}

Nos primeiros anos após as vitoriosas guerras de independência que assolaram os domínios espanhóis no continente, há uma nítida preferência ao nome Hispanoamérica em detrimento do nome América.

Es importante observar que, si bien se usaba la connotación 'española' o 'hispánica', esa calificación de América no respondía a una adhesión a España, a una suerte de hispanismo inicial. Era más bien una constatación de las raíces coloniales y de la vigencia de un idioma común y una misma religión, pero es claro que los protagonistas de la Independencia, sobre todo cuando el proceso ya estuvo avanzado en la segunda década del siglo, la veían como el enemigo, como un poder que había llevado adelante la barbarie de la conquista y la colonización, que estaban rompiendo y a la vez vengando. (MORA, 2012, p. 217)

Cabe lembrar, também, a insatisfação causada aos criollos quando chamados de americanos em suas viagens a metrópole, ainda no período colonial. Ao serem chamados de americanos, sentiam-se igualados aos indios, aos escravos e aos mestiços, algo que realmente não os agradava, de modo algum. De outro lado, as constantes agressões sofridas pelas repúblicas recém constituídas, desferidas por potencias europeias e, principalmente, os Estados Unidos, determinam a procura de um elemento de aproximação, tal elemento se expressa através da língua e da cultura hispânica. Um luta desigual entre duas Américas (FARRET; PINTO, 2011). 
Então, diante da sede expansionista dos Estados Unidos da América, expressa no lema América para os americanos (do norte), além do ressentimento e ódio pela exmetrópole, resulta na necessidade de diferenciar-se de ambos países, o nome América Latina, ganha força e se consolida. Agora, a região situada ao sul do Rio Bravo (divisa entre Estados Unidos e México) até o sul da Patagônia, passa a ser conhecida como América Latina, em oposição à América anglo-saxônica e protestante ao norte, caracterizada pela cultura latina e pela religião católica.

\subsubsection{Uma origem ainda controversa}

Ao voltarmos nossa atenção sobre a constituição de uma identidade latino-americana, encontramos, também, como uma importante expressão de sua complexidade o debate travado ainda hoje sobre a origem da ideia e do nome América Latina. A distinção feita entre a ideia e o nome América Latina decorre do interior do próprio debate acerca desse processo constitutivo.

De acordo com Leslie (2009), John Leddy Phelan ao publicar o ensaio Pan-Latinism, French Intervention in Mexico (1861-7) and the Genesis of the Idea of Latin America em 1968, apresenta e consagra o conceito de América Latina com sendo de origem francesa. Ainda de acordo com Leslie (2009), a expressão Amérique latine, utilizada com frequência por intelectuais franceses, justificaria e balizaria os interesses imperialista do imperador Napoleão III sobre o México e toda a região.

Contudo, segundo Ardão (1980) apud Farret (2011) o nome América Latina foi criado pelo jornalista colombiano, residente em Paris, José Maria Torres Caicedo em 1856. Entretanto, ainda, segundo Farret (2011) Arturo Ardao e John Leddy Phelan concordam sobre a gênese francesa da ideia de uma América Latina. Nesse momento a ideia América Latina referia-se apenas aos países de língua e cultura espanhola.

Não pense que terminou, existe ainda uma última controvérsia, de acordo com Farret (2011), Miguel Roxas Mix declara em seu livro, Los cien nombres de America que Arturo Ardao errou ao não indicar como sendo autor do nome América Latina o intelectual chileno Francisco Bilbao. O intelectual chileno teria utilizado a expressão América Latina em um discurso em que defende uma integração regional. Um discurso proferido três meses antes da poesia de Torres Caicedo ser publicada. Ainda de acordo com Farret (2011), Ardao não reconhece Bilbao como autor do nome América Latina, pois, o termo latina teria sido utilizada ainda como um adjetivo, enquanto Torres Caicedo o aplica como substantivo.

Aguardamos ainda mais novidades sobre esse debate. 


\subsubsection{Da ideia de latinidade à ideia latina}

Segundo Ardao (1986), há uma precedência da palavra latinidade sobre a ideia latina, bem como um deslizamento de significado da primeira sobre a segunda. A latinidade como conceito teria uma origem bastante antiga e designaria àqueles de fala latina, para mais tarde, englobar a todos as línguas neolatinas. Nesse sentido, aponta Ardao (1986), a nossa América Latina, já era latina, antes mesmo de receber essa denominação no século XIX. Já a ideia latina, seria expressão de uma ideologia latinista, tendo seu contorno definido no século XIX, apresentando entonações político instittucional.

Deste ponto, após um pequeno hiato, avançaremos ao próximo momento de crise assinalado por Larraín (1994).

\subsection{Entrando pela porta dos fundos}

O Brasil permanece distante dos debates iniciais sobre a identidade latino-americana, por diversos fatores, dentre eles, podemos afirmar que os mais significativos são, a língua e a cultura portuguesa e somado à monarquia. A uma pequena mudança nessa situação quando o movimento republicano declara Somos da América e queremos ser americanos. Após a proclamação da república, há uma movimento de aproximação entre o Brasil e seus vizinhos Argentina e o Chile e, mais fortemente, com os Estados Unidos. Um estreitamento de laços de tal maneira significativo que transforma o Brasil em grande defensor do pan-americanismo (BETHEL, 2009).

\subsection{De olho no passado e rumo ao futuro: entre 1920 e 1930}

De acordo com Larrain (1994), são publicadas inúmeros trabalhos que criticam ao mesmo tempo o caráter latino-americano e a adoção do racionalismo europeu por parte de um grupo de intelectuais e militante. Esses trabalhos, muitos de cunho indigenista, apontavam para a particularidade do ser latino-americano e a necessidade de uma valorização da cultura indígena. Contudo, para Larrían (1994) essa visão era ingênua e romântica. Apresentam o passado pré-colombiano de maneira idílica e idealizada.

Ainda segundo Larrain (1994), nos anos 30 surgem vários ensaios de escritores estrangeiros e latino-americanos sobre o caráter regional e

dos cosas fundamentales pueden notarse en estas versiones. Primero, resalta lo increíblemente pesimista que son en su evaluación de los vicios y limitaciones de la identidad cultural latinoamericana. Segundo, aparece una convergencia de opiniones sorprendente entre los autores extranjeros y los locales que muestra que las autopercepciones latinoamericanas de algún modo reflejan como en un espejo los prejuicios y estereotipos concebidos en el extranjero (LARRAÍN, 1994, p. 46). 
Tanto a visão ingênua dos indigenistas, como a visão pessimista sobre a identidade latino-americana presente nos anos 30, apontam, segundo, Larraín (1994), para um futuro incerto, pois os latino-americanos não seriam capazes de assimilar os valores e padrões europeus.

No plano prático, os governos procuram fomentar o desenvolvimento atacando os resíduos do sistema colonial, isto é, os latifundiários e a concentração de terras, ao mesmo tempo, fomentando a criação de parques industriais.

\begin{abstract}
La idea de desarrollo, de sociedades en transición a la modernidad mediante cambio social acelerado, era crucial. El modelo eran aquellos países en Europa y Norteamérica que ya se habian desarrollado. La lucha era contra los restos del sistema oligárquico controlado por las viejas aristocracias terratenientes. Por ello las reformas agrarias eran consideradas tan importantes para el proceso modernizador. La iniciativa económica y política para producir modernización e industrialización estaba principalmente en manos del Estado (LARRAÍN, 1994, 47).
\end{abstract}

A diminuição do poder dos grandes proprietários de terra e o crescimento dos movimentos operários são as grandes marcas desse período.

O sucesso ou o fracasso dessas políticas nos levam ao próximo momento de crise identitária.

\title{
2.5 Dos sonhos ao gosto amargo da desilusão: entre 1960 e 1970
}

O fracasso das políticas de industrialização abriram espaço para questionamentos sobre o sistema capitalista e a dependência dos países do terceiro mundo aos grandes centros industrializados. O fracasso dos diversos projetos de modernização levam ao fortalecimento das críticas de teor marxista.

Por el fracaso de la modernización capitalista, se culpaba principalmente al imperialismo. El capitalismo no era viable en América Latina porque era dependiente de los principales centros industriales. Esta fue la época del resurgimiento del marxismo y de los proyectos socialistas cuyos objetivos fundamentales eran la lucha contra la dependencia y el logro de un desarrollo nacional (LARRAÍN, 1994, p. 47).

Infelizmente, a crescente organização dos setores populares, por conseguinte, sua capacidade reivindicatória, resulta em um aumento na tensão das relações sociais. O acirramento dessas contradições leva os setores mais tradicionais da sociedade civil apoiem e defendam o estabelecimento de ditaduras cívico-militares em todo o continente. Suas tristes consequências todos nos conhecemos. Sequestros, torturas, desaparecimentos e 
mortes. Um salto humano mais do que negativo. No plano econômico, um pequeno milagre, seguido por um grande período de estagnação.

É nessa situação que chegamos aos anos 1980.

\title{
2.6 Na era da globalização: os cacos da história
}

Um discurso de caráter homogeneizador e totalitário, fim da história ou fim das ideologias, contudo, ao por em xeque as identidades regionais, cria, de modo inesperado, condições para virem à tona uma série de insatisfações ou questionamentos sobre uma determinada nomeação. Em nosso caso, a própria identidade latino-americana. Os estudos voltados aos grupos de resistência,

\begin{abstract}
como os grupos étnicos, as minorias religiosas, as culturas ameaçadas, as reivindicações de gênero, as competências profissionais, percebem a manutenção, ou mesmo o reforçamento, de referências estáveis a coletividades que lhes forneçam um lugar no mundo, ou seja, para voltar ao velho termo, uma identidade. Exemplos não faltam: identidades nacionais ou transnacionais, identidades culturais, identidades sexuais, identidades religiosas, identidades profissionais (PAIVA, 2007, p. 78).
\end{abstract}

Como resultado temos a organização e reivindicação dos povos originários, da demarcação de terras à autodeterminação.

Pouco a pouco, nos diferentes encontros do movimento dos povos indígenas, o nome América vem sendo substituído por Abya Yala, indicando assim não só outro nome, mas também a presença de outro sujeito enunciador de discurso, até então calado e subalternizado em termos políticos: os povos originários (PORTO-GONÇALVES, 2010, p. 26).

A organização e os movimentos de consciência negra, além de apresentarem uma grande agenda de reivindicações históricas, reafirmam a necessidade do reconhecimento da cultura negra na formação de nossa identidade podendo ser expressa na adoção do nome América Afro-Latina. Segundo, Andrews (2007), o nome e a ideia América AfroLatina, foi utilizada a primeira vez em artigos dos cientistas políticos Anani Dzidzienyo e Pierre-Michael Fontaine. Contudo, o termo se referia apenas aos países onde a influência da cultura africana era significativa, não à totalidade de nossa região. "Fontaine usou o termo para designar todas as regiões da América Latina em que são encontrados grupos significativos de pessoas de conhecida ascendência africana".(ANDREWS, 2007, p. 29).

É nesse campo de disputa política, marcado pelo ocultamento e pela resistência que desenvolvemos nossa análise sobre a identidade latino-americana. Será que um nome pode englobar toda nossa diversidade. Um conceito ampliado de América Latina é suficiente? O melhor nome seria mesmo, Abya Yala? Ou seria América Afro-Latina. 


\title{
3 Do autor e sua obra
}

\author{
"Nas longas noites de insônia e nos \\ dias de desânimo, aparece uma mosca \\ que fica zumbindo dentro da cabeça da \\ gente: VALE A PENA ESCREVER? \\ Será que as palavras sobreviverão em \\ meio aos adeuses e aos crimes? Tem \\ sentido este ofício que a gente \\ escolheu - ou pelo qual foi escolhido?" \\ Eduardo Galeano
}

\subsection{Os nascimentos}

Eduardo Hugues Galeano é um americano do sul. Assim se auto-definiu nos idos de 1976 na introdução publicada no seu livro Vozes e Crônicas o autor uruguaio nascido em Montevidéu em 3 de setembro de 1940. Já aos 14 anos começa a publicar desenhos e caricaturas políticas em El Sol, semanário socialista uruguaio. Assinava seus desenhos como Gius, versão castelhanizada de Huges, seu nome paterno (GALEANO, 1978). Nos anos de 1960 passou a escrever e se envolveu definitivamente com o jornalismo, exercendo a carreira de jornalista, trabalhando e dirigindo diferentes jornais e revistas, e com a literatura, tendo escrito vários livros - muito dos quais permanecem por longos anos proibidos em diferentes países latino-americanos, enquanto persistem as ditaduras militares pelo continente.

Também em Montevidéu faleceu em 13 de abril de 2015. Esta foi sua terceira e definitiva morte. Antes, em 1959, ainda aos 19 anos, tentou suicídio e pôs fim à sua primeira vida - até então desenhava para a revista Sol, angustiado tentava escrever para "tirar de dentro de mim essa fera que tinha crescido". Sentindo-se solitário e incapaz de escrever, escolheu um hotel e comprou luminal e acordou no hospital depois de dias em como. Da experiência ficaram as cicatrizes no corpo, na pele, "o corpo nunca me perdoou (...) mas isso era o de menos (...) tinha os olhos lavados: via o mundo pela primeira vez e queria comê-lo. Todos os dias seguintes seriam um presente" (GALEANO, 1978, ps. 4345). Desde então, passou a chamar-se de Eduardo Galeano em seus artigos e livros "um modo de dizer: sou outro, sou um recém nascido, nasci de novo" (GALEANO, 1978).

Depois, se pôs a morrer novamente em 1972 na Venezuela. Esteve no garimpo de diamantes na selva de Guaniamo para uma matéria jornalística que publicou na revista 
Expres Español ${ }^{1}$. Ali contraiu malária, as duas, "a benigna, e em seguida a brava", passou dias em um hospital - na saída "tinham me dado um certificado de ressurreição", conta o autor sobre sua segunda morte (GALEANO, 1978, p. 46). Desta experiência relata que saiu novamente mudado, havia confirmado que seu assunto era escrever: "aquela noite eu percebi que eu era um caçador de palavras. Para isso tinha nascido. Essa ia ser minha maneira de estar com os demais depois de morto e assim iam morrer totalmente as pessoas e as coisas que eu tinha querido" (GALEANO, 1978, p. 51)

\subsection{Um jornalista e seu tempo}

Galeano trabalhou, ainda, em um importante semanário de esquerda uruguaio, Marcha, semanário com vida longa, fundado em 1939 e fechado pela ditadura uruguaia em 1974, que circulava por diferentes países da América Latina e teve como seus colaboradores importantes intelectuais e políticos de diversas nacionalidades ao longo de sua existência ${ }^{2}$. Envolvidos pelas grandes mudanças que vinham ocorrendo em fins dos anos de 1950 e ao longo de 1960, Marcha foi o semanário de grande prestígio e um dos mais importantes centros de debates sobre os rumos que estavam tomando os países latino-americanos, as lutas sociais por transformações em curso no continente - as tentativas de revoluções na Bolívia e na Guatemala, a revolução em Cuba, as reformas de base de João Goulart no Brasil, os golpes e ditaduras militares no continente, entre outras lutas e acontecimentos estavam em debates em suas páginas.

O semanário acompanhava de perto a situação na América Latina, em particular Brasil e Cuba, os rumos que tomavam estes países estavam no centro de discussões. Em 1965, Marcha publica carta de Che Guevara endereçada à Carlos Quijano, fundador do semanário, "famosa carta pela qual defendia a formação 'do homem novo', revolucionário e solidário"(REIS, 2009, p. 477). Em 1968, o mesmo Quijano publica artigo em que defende a "integração revolucionária da América Latina ou da América do Sul (...) Pela pátria pequena, pensamos visceralmente agora, à pátria grande. Pelo socialismo à integração" (REIS, 2009, p. 477), explicitando a necessidade da unidade latino-americana para

1 O artido assinado por Galeano foi publicado na edição de setembro de 1972, como o título La Fiebre Del Diamante em Guaniamo, Venezuela, nele o autor narra o cotidiano dos garimpeiros com imagens da criação, do descobrimento, entremeando ao acontecimento real o extraordinário e os mistérios desta própria realidade: "para la persecución de dlos diamantes, los mineros se dejan guiar por el canto de ciertos pájaros y por algunos signos favorables en las arenas de los rios o en el fondo de la tierra. También se dejan guiar, a veces, por los sonidos o las imágenes de los sueños"(p. 7). Este artigo foi publicado posteriormente em seu livro Crônicas Latinoamericanas, de 1972, publicado no Brasil com o título Vozes e Crônicas - Che e outras histórias

2 Colaboraram com a Marcha muitos dos mais expressivos intelectuais e políticos do continente, dentre eles vale ressaltar os nomes de Pablo Neruda, Octavio Paz, Mario Benedetti, Gabriel Garcia Marques, Juan Onetti, Júlio Cortázar, Vargas Lhosa, Miguel Ángel Asturias, Carlos Drummond de Andrade, Che Guevara, Fidel Castro, João Goulart, Emilio Frugoni, Carlos Quijano (GALEANO, 1978, p. 171); (OLIVEIRA, 2013, p. 7). 
enfrentar os dramáticos acontecimentos no continente. Em seu trabalho, Reis (2009) sugere que aos intelectuais uruguaios estavam postas as condições político-sociais para que pudessem levar em conta a necessidade de integração latino-americana de maneira mais enfática antes de que outros de países do continente.

\subsection{Ainda um jovem}

Eduardo Galeano, com 20 anos de idade, estava em meio à esta efervescência como chefe de redação entre os anos de 1960 e 1964 - em maio de 1964, após o golpe militar, viajou ao Brasil e "entrevistou, entre outros, Leonel Brizola e Darcy Ribeiro. Antes porém, Francisco Julião (1964) enviou a Galeano um manifesto contra o governos militar, que foi publicado em Marcha" (REIS, 2009, p. 475). Viajou por diferentes países e conheceu as mais diversas realidades. Esteve na China Popular em 1963 e entrevistou Chu-Em-Lai, primeiro Ministro chinês. Permaneceu ali por dois meses, indo logo em seguida para a URSS, o que lhe permitiu escrever sobre o conflito sino-soviético ainda em seu início. Dali partiu para a Europa e depois aos Estados Unidos. Em 1964 entrevistou longamente Che Guevara e em 1996 esteve em com Juan Domingo Perón, na Argentina. Esteve na Guatemala, onde em 1967 conheceu a matança de milhares de guatemaltecos realizada pelo esquadrão da morte e esteve com os guerrilheiros nas montanhas (1978). Tornou-se um andarilho das Américas e estas muitas histórias colhidas é que se tornariam a matéria de muitos de seus livros e os levariam a escrever sobre o continente, sobre suas histórias e sobre seus personagens.

\subsection{O primeiro olhar sobre a América Latina}

Um ano antes de sua segunda morte, publicou As Veias abertas da América Latina, em 1971, seu livro mais conhecido, que se tornou nos anos seguintes uma importante referência sobre a América Latina e marcou várias gerações - somente no Brasil alcançou a marca de 50 edições até o ano de 2010. Permaneceu proibido durante anos na região, até a retomada da democracia no continente Galeano conta em entrevista a Eric Neponuceno que "queria fazer uma espécie de divulgação de algumas ideias que estão escritas em código pelos economista e sociólogos" (GALEANO, 1978, p. 165)

Na obra, expõe uma história comum à América Latina de espoliação e de dominação imperialista, que partilha dos mesmos opressores e que não cansa de se repetir ao longo dos muitos anos de sua formação e desenvolvimento. A respeito disto assinala no prefácio que fez à última edição brasileira: "por isto neste livro, que quer oferecer uma história de rapinagem e, ao mesmo tempo, mostrar como funciona os mecanismos atuais de espoliação, aparecem os conquistadores nas caravelas e, ali perto, os tecnocratas nos 
jatos" (GALEANO, 1972, p. 25). Mas ao mesmo tempo expõe um testemunho de lutas e resistências no continente nas histórias contadas sobre e pelo homem comum em um movimento de traze-lo à história da América Latina, uma busca para dar voz aos silenciados e desertados pela historiografia oficial. Em entrevista recente, após 43 anos de sua publicação Galeano afirma que "Veias abertas tentou ser um livro de economia política, só que eu não tinha a formação necessária ... (porém) não estou arrependido de tê-lo escrito, mas foi uma etapa que, para mim, está superada” (EBC, 2014)

Este duplo movimento ao narrar a história latino-americana trazendo junto aos grandes acontecimentos a visão dos de baixo, dos excluídos da história em As Veias abertas da América Latina, escrito em 90 noites para o prêmio Casa de las Américas (KOVACIC, 2015), prenuncia o que realizará na trilogia "Memória do Fogo" na década seguinte, nos anos de 1980.

\subsection{Uma viagem forçada}

Para além de viagens que fez por diferentes países e cidades como jornalista que era, Galeano se viu obrigado a sair do seu país com o Golpe Militar de 27 de junho de 1973, página obscura que lançou o Uruguai na longa noite escura das ditaduras que enfrentava o continente sulamericano. Exilou-se em Buenos Aires, Argentina, e ali fundou e dirigiu a revista Crisis, à época importante periódico de esquerda, até que também ali o peso das ditaduras se fizesse presente com o golpe militar em 1976. Seus companheiros de Crisis perseguidos, mortos ou desaparecidos, seu nome e de outros mais postos em listas de condenados à morte, Galeano se viu obrigado a deixar o país em direção à Madri, na Espanha, de onde regressou apenas em 1985, quando das primeiras eleições diretas após o término da ditadura (GALEANO, 1978, p. 13).

\subsection{Uma obra do desterro}

É no exílio espanhol que Galeano escrevere a trilogia Memória do Fogo, entre os anos de 1980 e 1986. Trata-se de uma obra de criação literária, em que faz uma cronologia de acontecimentos históricos e sociais das Américas, particularmente da América Latina, constrói um grande e vasto mosaico com histórias colhidas e apoiadas em base documental. Galeano afirma logo na apresentação do primeiro volume que não se trata de uma obra objetiva, que não há neutralidade neste seu relato da história, que incapaz de distanciamento, toma partido e conta à sua maneira cada uma das passagens que apresenta. Em um dos fragmentos literários de O Livro dos Abraços, de 2002, Galeano recorda a escrita de Memória do Fogo e fala deste seu envolvimento com as histórias que conta, sob o significativo título A Celebração da Subjetividade: 
Eu já estava há um bom tempo escrevendo Memória do Fogo, e quanto mais escrevia mais fundo ia nas histórias que contava. Começava a ser cada vez mais difícil distinguir o passado do presente: o que tinha sido estava sendo, e estava sendo a minha volta, e escrever era minha maneira de bater e abraçar. Supõe-se, porem, que os livros de historia não são subjetivos.

Comentei isso tudo com Jose Coronel Urtecho: neste livro que estou escrevendo, pelo avesso e pelo direito, na luz ou na contra luz, olhando do jeito que for, surgem a primeira vista minhas raivas e meus amores.

E nas margens do rio San Juan, o velho poeta me disse que não se deve dar a menor importância aos fanáticos da objetividade: - Não se preocupe - me disse - . E assim que deve ser. Os que fazem da objetividade uma religião, mentem. Eles não querem ser objetivos, mentira: querem ser objetos, para salvar-se da dor humana (GALEANO, 2002, p. 118).

De volta à apresentação do primeiro volume da trilogia, Galeano ressalta, no entanto, que "cada fragmento deste vasto mosaico se apoya sobre una sólida base documental"(GALEANO, 1991, p. XII), e oferece ao final de cada volume a lista com as referências às fontes consultadas, que contabilizam mais de mil fontes.

As obras Os Nascimentos, As Caras e as Máscaras e O Século do Vento são na ordem seus três volumes, que se estruturam por meio de pequenos textos independentes e se apresentam como unidade: estão ali 500 anos de história da América, particularmente da América Latina, e de sua criação mítica pelos povos que aqui viviam.

Os Nascimentos, o primeiro volume, está dividido em duas partes. A primeira parte, chamada Primeiras Vozes, uma América pré-colombiana aparece num mosaico de mitos indígenas de fundação, mitos sobre o surgimento do mundo e do homem, da constituição e criação da natureza, numa espécie de Teogonia latino-americana dispersa pelos povos originários, que uma vez reunidos remete a tempos imemoriais as origens múltiplas da existência, a um tempo da tradição que somente a oralidade pode transmitir. Com isto Galeano demarca o rumo que tomará sua obra desde as suas primeiras páginas, o de contar as histórias não com o rigor científico do historiador, mas com o rigor de quem transmite uma tradição, de quem conta o passado para que as vozes passadas não se percam e possam ser ouvidas pelas gerações: "Cuanto aquí cuento, ha ocurrido; aunque yo lo cuento a mi modo y manera" (GALEANO, 1991, p. XII), a um modo e maneira de quem transmite uma tradição. Em sua segunda parte, chamada Velho Novo Mundo, constrói o percurso da colonização entre 1492 e 1700 em um mosaico de ação, submissão e resistência.

O segundo volume, As Caras e as Máscaras, abarca os séculos XVIII e XIX, o empreendimento colonizador, as lutas pelas independências e os sonhos da Pátria Grande, seus heróis e caudilhos. Narra o período formativo do que virá a ser o continente hoje. O Século do Vento, terceiro e último volume de Memória do Fogo, conta o breve século XX sugerido no próprio título, entre os anos de 1900 e de 1984, período fortemente marcado 
pelas difíceis relações com o gigante do norte, os EUA e sua política imperialista para a América Latina. Revela a realidade contemporânea em um mosaico construído de uma maneira que o imperialismo aparece como passado e presente, como ocorrido, como ocorrendo e como possibilidade de tornar a ocorrer. É também o século de Galeano, este século do vento em que conta também as histórias que ele mesmo colheu em suas viagens pela América e pelo mundo, além das que colheu em fontes históricas.

\subsection{Memórias vindas do esquecimento}

Em Memória do Fogo, Galeano parte da compreensão, já presente em As Veias abertas da América Latina, de que a América Latina vem sendo despojada ao longo dos séculos não só de suas riquezas materiais, mas também de sua memória, condenada à amnésia e ao esquecimento de seu processo de constituição e de suas raízes, usurpada na história oficial. Reafirma, não é um historiador, é um escritor. Propõe-se em cada uma das apresentações para cada volume da obra contribuir para o resgate da memória, narrar a história e contar o ocorrido. No primeiro volume quer "contribuir al rescate de la memoria secuestrada (...) conversar con ella, compartirle los secretos, preguntarle de qué diversos barros fue nacida, de qué actos de amor y violaciones viene" (GALEANO, 1991, p. XII). No segundo, "se propone narrar a historia (...) revelar sus múltiples dimensiones y penetrar sus secretos" (GALEANO, 1994, p. XII). No terceiro, "cuenta lo que ha ocurrido (...) y quisiera hacerlo de tal manera que el lector sienta que lo ocurrido vuelve a ocurrir cuando el autor lo cuenta" (GALEANO, 1986, p. XIV).

Resgatar a memória, narrar a história e contar o ocorrido desde o ponto de vista dos deserdados, que é onde se põe o autor ao recusar a neutralidade, para compartilhar os segredos, encontrar a diversidade que a fecundou e a compõe, penetrar seus segredos e revelar sua multiplicidade de tal maneira que se produza no leitor a sensação de que aquilo que foi volta a ser na medida em que ouve contar, é a proposta perseguida pelo autor nesta obra.

Galeano alcança mostrar a brutal exploração material e humana dos povos que vieram a compor a América Latina à medida em que a história dos grandes processos aparece em tensão com as histórias locais e muitas vezes personalizadas, à medida em que grandes personagens da História convivem lado a lado com os de baixo, grandes acontecimentos se vem contrapostos a pequenas ocorrências, o particular e o geral ambos fundamentais para a formação de nossa América. Distintamente de as Veias abertas da América Latina, onde a economia política é a chave para revelar a América Latina e suas contradições, a trilogia Memória do Fogo é a construção desta América Latina que se revela no processo histórico contraditório de submetimento e submissão e de resistência dos povos de qualquer canto da América, submetidos ao aniquilamento e à exploração. 
Memória do Fogo é uma obra de desterro. Galeano escreve distante de sua terra, com as ditaduras e o terror espalhados pelas terras latino-americanas, esteve impedido de caminhar pelo continente e compartilhar com cada povo as lutas e as labutas cotidianas, escreve, também, para compensar essa distância e manter-se próximo de seu povo. Para enfrentar a desmemoria, o esquecimento. Em outro fragmento de O Livro dos Abraços, conta que na Galícia, em tempos de Roma Imperial, os legionários jamais haviam avançado para além das margens do rio do Esquecimento:

...paralisados de pânico, tinham parado nas margens daquele rio. E não o haviam atravessado nunca, porque quem cruza o rio do Esquecimento chega a outra margem sem saber quem é ou de onde vem. Eu estava começando meu exílio na Espanha, e pensei: se bastam as águas de um rio para apagar a memória, o que acontecerá comigo, que atravessei um mar inteiro? (GALEANO, 2002, p. 112)

Acontece ao autor que ele irá dedicar-se à memória e à história da América Latina. A distância em suas múltiplas dimensões imposta pelo exílio fará Galeano dedicar-se a pesquisar sobre o presente e o passado e construir uma narrativa que irá em sentido oposto ao esquecimento, à amnésia continental. Ao sequestro da memória Galeano empreende uma história a contrapelo. Constrói uma história a partir de rastros, cada fragmento em Memória do Fogo conta uma história, um acontecimento, que se constituem em vozes dispersas pelo continente. Justapostos, os rastros vão compor uma história da América Latina, cujas vozes se articulam em uma polifonia.

Talvez não seja demasiado arriscado sugerir que Galeano tenta e alcança realizar uma obra épica moderna sobre a América Latina à maneira de Gregos, Romanos e Lusitanos. Mas de modo distinto. O herói é o povo e está no povo latino-americano, é particularmente aquele que não tem voz, que aparece ora na sua dimensão singular, ora na sua dimensão coletiva, heroísmo que se refere aos de baixo, aos que não têm voz. Mas Galeano não se detém a esta definição literária e ironiza: "Ignoro a qué género literario pertenece esta voz de voces (...) No creo en las fronteras que, según los aduaneros de la literatura, separan a los gêneros"(GALEANO, 1991, p. XII).

Memória do Fogo encerra-se quando também se encerra o exílio espanhol do autor. Em seu último volume da trilogia Memória do Fogo, Galeano termina com uma breve carta escrita já em Montevidéu em 1986 ao editor em que arrisca explicar porque termina este século do vento em 1984: "Como verás, acaba em 1984. Por qué no antes, o después, no sé. Quizás porque ése fue el último año de mi exilio, el fin de un ciclo, el fin de un siglo" (GALEANO, 1986, p. 248). 


\subsection{O retorno do andarilho}

De fato, em 1985 retornou ao Uruguai após a volta da democracia no país com a eleição de Julio María Sanguinetti e com outros jornalistas e colaboradores do Marcha, como Mario Benedetti, fundou o semanário Brecha. Nos anos seguintes publicou outras tantas obras, como As Palavras Andantes, ilustrado por J. Borges, O Futebol a Sol e Sombra, com crônicas sobre uma de suas paixões, De pernas pro ar - A escola do mundo ao avesso, em que constata e denúncia o mundo posto ao avesso pelo neoliberalismo, e "Os Filhos dos Dias", seu último livro publicado em vida.

O levante Zapatista em 1994 no México contou desde início com seu apoio e Galeano estabeleceu uma relação profunda com o zapatismo e o subcomandante Marcos. Nos anos 2000 se envolveu ativamente com O Fórum Social Mundial, participando de seus inúmeros encontros e contribuindo com a articulação da luta contra a globalização e as políticas neoliberais que assolaram fortemente o continente nos anos de 1990 e 2000 . Em 2008 tornou-se o primeiro cidadania ilustre do Mercosul, título de mérito do Mercosul, em reconhecimento à sua contribuição à cultura, à identidade latino-americana e à integração regional. Permaneceu até sua morte em 2015 denunciando os arranjos de exploração e alienação do sistema econômico, um sistema de morte que segundo o autor se baseia numa indústria do medo que impede os homens e as mulheres de sonhar. Mas Galeano seguia dizendo que há um outro mundo na barriga deste mundo esperando para nascer, um mundo diferente. 


\section{Da obra a uma reflexão sobre a latinidade}

Coisas que a gente se esquece de dizer Coisas que o vento vem as vezes me lembrar

Coisas que ficaram muito tempo por dizer

$\mathrm{Na}$ canção do vento não se cansam de voar.

Lô Borges e Ronaldo Bastos

\subsection{Um breve prelúdio II}

Ao iniciarmos nossas reflexões sobre a identidade latino-americana, possuíamos duas grandes certezas, a primeira, o carácter histórico e dinâmico do processo identitário, a segunda, decorrente da primeira, a necessidade de procurarmos na história de formação do continente americano, onde o processo de constituição identitário apresenta-se inserido, os elementos determinantes para a constituição de nossa identidade social, resultado da correlação de forças sociais aqui existentes. A América Latina, mesmo existindo de forma concreta, materializada em projetos políticos-sociais e instituições, representa nossa real diversidade.

De posse dessas duas certezas, buscamos estabelecer uma abordagem que permitisse, ao mesmo tempo, acompanhar e resgatar a multiplicidade narrativa presente no processo de constituição do que hoje designamos como América Latina, fruto de nossa diversidade étnica, cultural, social e histórica. Encontramos respostas às nossas indagações quando, com base na crítica benjaminiana sobre a modernidade que, ao apontar e lamentar o desaparecimento da narrativa tradicional, também aponta para a necessidade da construção de outras formas narrativas. Então, ao nos aproximarmos da história, por meio de seu elemento narrativo, encontramos, além de mais um aspecto para auxiliar nossa compreensão das teses Sobre o conceito de História (BENJAMIN, 1994), nossa primeira justificativa para a adoção da obra Memória do Fogo como fonte para nossas análises sobre o processo identitário latino-americano, bem como, determinar o campo de nossas reflexões.

Se não determino aqui de que gênero de narração nem de que gênero de sujeito se trata, quer seja, por exemplo, a longa narrativa das historiai de Heródoto lidas ao povo ateniense, ou, então, o relato solitário e balbuciante da psicanálise, do qual não se sabe sempre nem quem o enuncia nem a quem se dirige, é porque quero pensar este núcleo narrativo comum à história como processo real (como Geschichte), à história como 
disciplina (como Historie), a história como narração (como Erzahlung). Há, portanto, de início, a convicção de esta homonímia, à qual estamos acostumados, nos indica uma comunidade de significação mais forte que a oposição habitual entre 'histórias' (plural) que seriam contadas para desviar dos fatos e a 'história' (singular) que deveria restituir a verdade do passado. Convicção também de que literatura e história (Historie) andam juntas sem que isso signifique, necessariamente, um relativismo resignado da 'ciência histórica' ou um relativismo militante da literatura. (GAGNEBIN, 1994a, ps. 2-3)

Uma segunda e tão importante justificativa, sobre nossa escolha, relaciona-se diretamente à biografia do autor, sua militância política de esquerda, seu olhar sempre atento às questões sociais latino-americanas, seu envolvimento direto em acontecimentos nos mais diversos cantos do continente e sua atenção aos pequenos episódios, aqueles que não se tornam fatos históricos, mas fazem parte do todo desse processo. Contudo, somente a produção de uma escrita engajada, não justificaria por si, a nossa escolha, porque, não há uma obra de arte engajada, sem se constituir em uma obra de arte completa em todos os seus sentidos. O elemento estético, em uma obra de arte, não pode jamais ser descartado como um elemento secundário e, nem o será, por nós.

\footnotetext{
A tendência de uma obra literária só pode ser correta do ponto de vista político quando for também correta do ponto de vista literário. Isso significa que a tendência politicamente correta inclui uma tendência literária. Acrescento imediatamente que é essa tendência literária, e nenhuma outra, contida implícita ou explicitamente em toda tendência política correta, que determina a qualidade da obra. Portanto, a tendência política correta de uma obra inclui sua qualidade literária, porque inclui sua tendência literária (BENJAMIN, 1994, p. 121).
}

Entretanto, antes de começarmos nossa análise sobre a constituição da identidade latino-americana a partir da obra Memória do Fogo, gostaríamos de apresentar algumas semelhanças tanto entre a obra como a vida de Walter Benjamin e Eduardo Galeano. Semelhanças que tornaram-se visíveis aos nossos olhos enquanto procurávamos nos aprofundar em nossos estudos. Nos aprofundávamos, mas, ainda assim, com a sensação de permanecermos na superfície.

\subsection{Das semelhanças: uma pequena pausa em nosso percurso}

Ao nos aproximarmos tanto da obra filosófica de Walter Benjmain como da obra literária de Eduardo Galeano, percebemos algumas semelhanças que, apesar de não relacionadas diretamente com a nossa reflexão, não consideraríamos deixar de assinalá-las. 
de citações excepcionais, e não só de séries de acontecimentos parecidos. O incomum ou a exceção, quando são significativos, remetem ao geral pelo caminho do contraste iluminador. Naturalmente esse contraste não pode ser arbitrário. A forma da evidência histórica, pensa Benjamin, encontra-se nas imagens que condensam, como a iluminação poética, elementos muito longínquos, cujo vínculo era secreto, mas não imotivado (SARLO, 2012, p. 35).

Beatriz Sarlo, ao procurar descrever o método de investigação e apresentação de Walter Benjamin, sem saber, descreve de maneira muito próxima a maneira como Eduardo Galeano compõem, entre outras tantas obras, Memória do Fogo. Então, vejamos o trecho a seguir:

Frente a la isla de Uruana, Humboldt conoce a los indios que comen tierra.

Todos los años se alza el Orinoco, el Padre de los ríos, y durante dos o tres meses inunda sus orillas. Mientras dura la creciente, los otomacos comen suave arcilla, apenas endurecida al fuego, y de eso viven. Es tierra pura, comprueba Humboldt, no mezclada con harina de maíz ni aceite de tortuga ni grasa de cocodrilo.

Así viajan por la vida hacia la muerte estos indios andantes, barro que anda hacia el barro, barro erguido, comiendo la tierra que los comerá (GALEANO, 1994, p. 87).

Com certeza, no pequeno fragmento acima, percebemos em Galeano o mesmo cuidado ao destacar o incomum na construção de uma imagem a partir de sua descrição. O mesmo cuidado com que, Benjamin apresenta na construção de seus argumentos e paradoxos filosóficos. Poderíamos marcar além da presença do incomum e do inusual, a existência de uma contradição cultural bastante forte e expressa na surpresa de Humbolt diante dos hábitos alimentares dos orinocos. Esse estranhamento seria um elemento de semelhança em virtudade das tensões e contradições do pensamento benjaminiano. Contradições, que se consolidam ao longo de todas as obras de Benjamin. No caso da obra, Memória do Fogo, de Eduardo Galeano, as diversas contradições presentes nos pequenos fragmentos, compõem ao final da obra, um panorama geral de nossas contradições.

\subsubsection{Duas grandes obras do desterro}

Uma outra e importante semelhança entre nossos dois excepcionais autores, a produção de duas grandes obras escritas parcialmente no exílio. Duas obras que se ocupam da memória como tema. Uma delas, infelizmente, não concluída (1927-1940). A outra, concluída no retorno do exílio (1973-1986). A primeira, intitulada como Passagens. A segunda, intitulada Memória do Fogo. Ambas de grande fôlego e extensão.

Duas obras que por sua estrutura abrem-se para inúmeras interpretações. Passagens, obra inconclusa em virtude da prematura e trágica morte de seu autor. 
A edição das 'Notas e Materiais' talvez fascine por isso mesmo: se, em vez dos fragmentos, ali estivesse o livro terminado, todos os livros hipotéticos se teriam perdido e só haveria esse realmente existente. A obra de Benjamin se encerraria, talvez, com um magnífico livro. Hoje, fica aberta às reconstruções, atravessada pela incompletude. Mas essa incompletude não é precisamente um traço compositivo benjaminiano? Como leríamos hoje todo o Benjamin, se a promessa do livro das passagens tivesse sido cumprida? (SARLO, 2012, ps. 32-33)

Memória do Fogo, obra concluída no retorno do exílio, realiza, por meio de sua estrutura fragmentada e justaposta, um convite explicito a um reencontro com nossa história e, por conseguinte, com nossa identidade.

Ojalá Memoria del fuego pueda ayudar a devolver a la historia el aliento, la libertad y la palabra. A lo largo de los siglos, América Latina no sólo ha sufrido el despojo del oro y de la plata, del salitre y del caucho, del cobre y del petróleo: también ha sufrido la usurpación de la memoria. Desde temprano ha sido condenada a la amnesia por quienes le han impedido ser. La historia oficial latinoamericana se reduce a un desfile militar de próceres con uniformes recién salidos de la tintorería. Yo no soy historiador. Soy un escritor que quisiera contribuir al rescate de la memoria secuestrada de toda América, pero sobre todo de América Latina, tierra despreciada y entrañable: quisiera conversar con ella, compartirle los secretos, preguntarle de qué diversos barros fue nacida, de qué actos de amor y violaciones viene (GALEANO, 1991, p. XII).

\subsubsection{O suicídio e a morte. O suicídio e os nascimentos}

Há mais uma grande semelhança entre nossos autores. Uma semelhança de dor e desesperança. Uma tragicamente levada a cabo. A outra com o significado de um renascimento.

O suicídio de Benjamin em setembro de 1940 é a execução de um gesto no qual havia pensado muitas vezes. Em Marselha, na véspera de sua partida para Port Bou, ele havia, casualmente, encontrado o escritor Arthur Koestler, que também fugia dos alemães, e partilhara com ele seus cinqüenta tabletes de morfina. Os sete últimos anos de vida de Benjamin constituem-se numa fuga sem trégua da perseguição política e também numa luta perpétua pela sobrevivência material. Quando Benjamin deixa Berlim, em 18 de março de 1933, três semanas após o incêndio do Reischstag pelos nazistas e a onda de prisões que se seguiu (na noite do incêndio, mais de dez mil oposicionistas de esquerda presos), ele não possuí nenhuma fonte estável de ganhos. O poder crescente do partido nazista fez com que os meios de comunicação de massa renunciassem a seus colaboradores de esquerda ou de origem judaica. Benjamin, que trabalhava regularmente para diversas revistas e para o rádio, conta somente com uma promessa de trabalho bastante vaga do Instituto de Pesquisa Social (Institut für Sozialforschung) (GAGNEBIN, 1982, p. 9).

Uma tragédia pessoal e humana. 
No caso de Eduardo Galeano, sua tentativa de suicídio, resulta apenas na morte de sua primeira vida, como ele mesmo diz. Desse evento doloroso ficam "os olhos lavados: via o mundo pela primeira vez e queria comê-lo. Todos os dias seguintes seriam um presente" (GALEANO, 1978, p 45). Um presente para nós, seus leitores atuais e futuros.

\subsection{Um retorno à teoria}

Segundo Benjamin (1994) o avanço da Modernidade rompe os laços que constituíam as comunidades tradicionais, o meio de produção artesanal e seu ritmo lento e humano são substituídos, pelo ritmo frenético da fábrica e sua linha de montagem. A totalidade se vê fragmentada em pequenos pedaços que se movem na velocidade de uma linha de montagem. Os laços comunitários que sustentavam a palavra comum e, por conseguinte, uma vivência e experiência coletiva (Erfahrung), são destroçados na mesma velocidade. As experiências tornam-se vazias de sentido, porque, agora, individuais (Erlebnis) em sua essência, já não encontram eco e sustentação no meio social.

O desaparecimento da possibilidade de uma experiência coletiva (Erfahrung) relacionase de modo direto ao fim das narrativas tradicionais.

Um experiência quase cotidiana nos impõe a exigência dessa distância e desse ângulo de observação. É a experiência de que a arte de narrar está em vias de extinção. São cada vez mais raras as pessoas que sabem narrar devidamente. Quando se pede num grupo que alguém narre alguma coisa, o embaraço se generaliza. É como estivéssemos privados de uma faculdade que nos parecia segura e inalienável: a faculdade de intercambiar experiências (BENJAMIN, 1994, ps. 197-198).

De acordo com Gagnebin (1994b), Benjamin de maneira implícita, relaciona a reconstrução da experiência coletiva (Erfahrung) à criação de novas formas narrativas. Uma ação que só poderia ser levada a cabo, por aqueles que perceberam essa ruína e procuram criar novas formas de narração.

\footnotetext{
A uma experiência e uma narratividade espontâneas, oriundas de uma organização social comunitária centrada no artesanato, opor-se-iam, assim formas 'sintéticas' de experiência e de narratividade, como diz Benjamin referindo-se a Proust, frutos de um trabalho de construção empreendido justamente por aqueles que reconheceram a impossibilidade da experiência tradicional na sociedade moderna e que se recusa a se contentar com a privacidade da experiência vivida individual (Erlebnis) (GAGNEBIN, 1994b, ps. 9-10).
}

Da percepção da impossibilidade de um intercâmbio de experiências à demanda pela criação de novas formas narrativas e o reconhecimento do núcleo narrativo comum tanto na literatura como na ciência histórica, podemos afirmar que a crítica benjaminiana 
à historiografia existente na época de ascensão do Nazi-fascismo na Europa é anterior à redação de suas teses Sobre o conceito de História (1940), estando já contidas em seus textos O Narrador (1936) e Experiencia e Pobreza (1933). É a partir dos elementos críticos e descritivos presentes nessas reflexões benjaminianas que pudemos enxergar em Eduardo Galeanos, a figura do narrador e do historiador.

\title{
4.4 Eduardo Galeano: o narrador
}

Segundo Benjamin, só podemos elaborar uma imagem mais próxima do narrador se tivermos em mente os seus dois grupos originários, o viajante e o homem que conhece a fundo a história e as tradições de sua comunidade.

\begin{abstract}
'Quem viaja tem muito que contar', diz o povo, e com isso imagina o narrador como alguém que vem de longe. Mas também escutamos com prazer o homem que ganhou honestamente sua vida sem sair do seu país e que conhece suas histórias e tradições. Se quisermos concretizar esses dois grupos através dos seus representantes arcaicos, podemos dizer que é exemplificado pelo camponês sedentário, e outro pelo marinheiro comerciante (BENJAMIN, 1994, ps. 198-199).
\end{abstract}

Grosso modo, Eduardo Galeano não se enquadra em nenhuma dessas definições, entretanto, traz característica das duas. Sua profissão de jornalista, permitiu viajar e correr o Mundo, escolhe muitas vezes estar presente enquanto acontecimentos graves e importantes se desenrolavam. Sua vinda ao Brasil, logo após o golpe cívico-militar de 1964 representa bem essa atitude e desprendimento. Como navegante, Galeano foi um eterno andarilho. Como camponês sedentário, sempre esteve atento e presente aos momentos decisivos de nossa história.

Além disso, os pequenos fragmentos que compõem Memória do Fogo, os quais são compreensíveis em si mesmos e narrados de forma bastante concisa, facilita a assimilação e a compreensão da história contada, assim, como descreve o modelo de narração apresentado por Walter Benjamin.

Nada facilita mais a memorização das narrativas que aquela sóbria concisão que as salva da análise psicológica. Quando maior a naturalidade com que o narrador renuncia às sutilezas psicológicas, mais facilmente a história se gravará na memória do ouvinte, mais completamente ela se assimilará à sua própria experiência e mais irresistivelmente ele cederá à inclinação de recontá-la um dia (BENJAMIN, 1994, p. 204)

Uma característica marcante e pessoal dos grandes narradores refere-se ao seu processo de aprendizagem, e marca de forma indelével sua relação com o outro, sua proximidade e afinidade com as coisas que o cerca. "A experiência que passa de pessoa a 
pessoa é a fonte a que recorrem todos os narradores" (BENJAMIN, 1994, p. 198). Vejamos, então, como foi o processo de aprendizagem de Eduardo Galeano, em sua própria versão.

- Fue despues com decurso de los años que yo aprendi... Aprendi, principalmente en los cafes como este... Como este que estamos charlando ahora... aprendi a los cafes, la arte de narrar.

- Con estos narradores anonimos, amigos, gente que pasava... tines grandes narradores, capazes de lograr que algo que habia ocorrido volviéra a ocurrir quando se contava... que esta es la clave de la arte de narrar (ARGENTINA, SD).

A força da arte de narrar se encontra na possibilidade de partilhar não só uma experiência, mas uma que consiga fazer o tempo andar mais parar. Uma que consiga fazer o passado reviver no presente. A narração é de acordo com Galeano e Benjamin a possibilidade de despertarmos o fluxo infinito da memória com sue companheiro o esquecimento.

Pelo exposto até aqui, acreditamos que a imagem de Eduardo Galeano como um grande contador de histórias da América Latina seja totalmente justificável.

\subsection{Eduardo Galeano: o historiador}

Para Benjamin (1994), a historiografia burguesa e a historiografia progressista existente a época da Republica de Weimar tem em comum o tempo vazio e linear. Um tempo que se estrutura como uma linha de montagem, onde respiração e pausa são impensadas, não sobrando espaço para um pensamento criativo.

O historicismo culmina legitimamente na história universal. Em seu método, a historiografia materialista se distancia dela talvez mais radicalmente que de quaquer outra. A história universal não tem uma armação teórica, seu procedimento é aditivo. Ela utiliza a massa dos fatos, para com eles preencher o tempo homogêneo e vazio (BENJAMIN, 1994, p. 231).

Como a própria linha de montagem que engole Chaplin em Tempos Modernos. Ao contrário, a composição fragmentária de Memória do Fogo rompe com o fluxo continuo da linha de montagem. Os fragmentos narrativos, como pequenas mônadas, comportam em si mesmos os seus significados. Contudo, ao comporem como os demais fragmentos narrativos, mônadas, constroem um todo, com seu próprio significado. Cabe a nós, buscarmos seus significados. O fluxo da história não é linear, mas construído por semelhanças.

Galeano como imagem de um historiador marxista, descrito por Benjamin (1994), não perde os detalhes, nada lhe foge aos olhos. O comum e o discreto ganham a mesma 
importância dos grandes acontecimentos. Nada é insignificantemente pequeno que não deve ser percebido e apresentado. Nada é tão grandioso que não possa ser relativizado.

Quizás el pulque devuelve a los indios sus viejos dioses. A ellos lo ofrecen, regando la tierra o el fuego o alzando el jarro a las estrellas. Quizás los dioses sigan sedientos del pulque que mamaban de las cuatrocientas tetas de la madre Mayahuel.

Quizás beban los indios, también, por darse fuerza y vengarse; y seguramente beben para olvidar y ser olvidados.

Según los obispos, el pulque tiene la culpa de la pereza y de la pobreza y trae idolatría y rebelión. Vicio bárbaro de un pueblo bárbaro, dice un oficial del rey: bajo los efectos del espeso vino de maguey, dice, el niño reniega del padre y el vasallo de su señor (GALEANO, 1994, p. 68).

Por fim, Eduardo Galeano, mais uma vez assume a imagem do historiador marxista apresentado por Benjamin (1994), quando ao buscar fatos e acontecimentos esquecidos na história, faz um trabalho contrário ao de Penélope, que tecia um chalé durante os dias e o desfiava durante as noites enquanto espera seu esposo Ulisses. Nosso autor, entretanto, busca através de rastros deixados ao longo da história, recontar e reconstruir a história dos desertados da terra, os vencidos.

\subsubsection{Da estrutura da obra}

Com o declínio da arte de narrar, encontramos a demanda pela criação de novas formas narrativas que restabeleçam a troca de experiências e, ao nosso entender, Eduardo Galeano alcança esse intento quando, em sua obra Memória do Fogo, constrói uma nova forma narrativa enquanto apresenta a história da América Latina entrecortada por pausas e silêncios, silêncios repletos de significados, é verdade. Não há uma continuidade linear em sua história, apenas uma justaposição de acontecimentos que se abrem e denotam diversas interpretações. Galeano como Heródoto, não explica os fatos, apenas os descreve. Então, vejamos o que Benjamin fala sobre a verdadeira arte de narrar ao compará-la à informação.

\footnotetext{
...A informação só tem valor no momento em que é nova. Ela só vive nesse momento, precisa entregar-se inteiramente a ele e sem perda de tempo tem que se explicar nele. Muito diferente é a narrativa. Ela não se entrega. Ela conserva suas forças e depois de muito tempo ainda é capaz de se desenvolver (BENJAMIN, 1994, p. 204).
}

Contudo, de uma maneira bastante diversa das narrativas tradicionais, Galeano consegue (re)produzir por meio da estrutura narrativa de Memória do Fogo, através de seus pequenos fragmentos narrativos, o "o movimento infinito da memória, notadamente popular" (GAGNEBIN, 1994b, p. 13). Em Mil e Uma Noites, uma história chama outra história, em Memória do Fogo, a quebra e a descontinuidade dos acontecimentos buscam alcançar o mesmo objetivo, colocar em movimento a infinitude do processo de rememoração. 


\subsection{O que nos diz a obra}

Memória do Fogo de um modo geral apresenta passagens pouco ou totalmente conhecidas por nós, nesse sentido, evidência elementos que permitem um questionamento da histografia oficial sobre a formação da América Latina, por conseguinte de nossa própria identidade latino-americana. De uma outra perspectiva podemos dizer que, Galeano, procura devolver a dignidade dos vencidos. Um resgate levado a cabo pela nomeação aos esquecidos e da importância cultural dos diversos grupos sociais que se encontram marginalizados ao longo de todo o nosso processo civilizatório. De acordo com Lisboa (2014), a renomeação realizada pelos colonizadores, além de mostrar a posse da terra, facilita a colonização mental do povos originários. A nomeação por parte de Galeano aponta uma busca em sentido a tomada de consciência.

Ao resgatar essa dignidade usurpada, Galeano mostra, também, toda a violência que foi e, ainda é, desferida sobre os povos originários, os negros, as mulheres e as classes populares. Ao mesmo tempo, somos apresentados às diversas formas e estratégias de resistência. A simbólica. As revoltas e as rebeliões ocorridas em nosso continente.

Interessante notar que, Galeano ainda situa as contradições presentes na América Latina dentro do contexto mundial, isto é, dentro de um quadro amplo das relações internacionais.

Segue, a partir de agora, alguns exemplos retirados da obra Memória do Fogo.

\subsection{Um passado esquecido}

O primeiro movimento de Galeano é resgatar as tradições e costumes aqui existentes antes da chegada dos colonizadores. A partir de um conjunto de mitos e tradições somos apresentados à diversidade étnica e cultural aqui existente.

La mujer y el hombre soñaban que Dios los estaba soñando.

Dios los soñaba mientras cantaba y agitaba sus maracas, envuelto en humo de tabaco, y se sentía feliz y también estremecido por la duda y el misterio.

Los indios makiritare saben que si Dios sueña con comida, fructifica $y$ da de comer. Si Dios sueña con la vida, nace y da nacimiento.

La mujer y el hombre soñaban que en el sueño de Dios aparecía un gran huevo brillante. Dentro del huevo, ellos cantaban y bailaban y armaban mucho alboroto, porque estaban locos de ganas de nacer. Soñaban que en el sueño de Dios la alegría era más fuerte que la duda y el misterio; y Dios, soñando, los creaba, y cantando decía:

- Rompo este huevo y nace la mujer y nace el hombre. Y juntos vivirán y morirán. Pero nacerán nuevamente. Nacerán y volverán a morir y otra vez nacerán. $Y$ nunca dejarán de nacer, porque la muerte es mentira. (GALEANO, 1991, p. 16). 
O fragmento citado anteriormente representa o mito makiritare de criação do homem e da mulher.

Nube dejó caer una gota de lluvia sobre el cuerpo de una mujer. A los nueve meses, ella tuvo mellizos.

Cuando crecieron, quisieron saber quién era su padre.

- Mañana por la mañana — dijo ella —, miren hacia el oriente. Allá lo verán, erguido en el cielo como una torre.

A través de la tierra y del cielo, los mellizos caminaron en busca de su padre. Nube desconfió y exigió:

- Demuestren que son mis hijos. Uno de los mellizos envió a la tierra un relámpago. El otro, un trueno. Como Nube todavía dudaba, atravesaron una inundación y salieron intactos.

Entonces Nube les hizo un lugar a su lado, entre sus muchos hermanos y sobrinos. (GALEANO, 1991, p. 17).

Um mito transcrito de um livro francês sobre mitos, lendas e contos populares da América.

\subsection{Uma reconquista}

Em nossa historiografia oficial, parece que não existiu nenhum movimento de resistência dos povos originários diante a invasão sofrida, contudo, os confrontos se estenderam bem mais do que temos conhecimento. Até hoje, podemos dizer.

Hernán Cortés pasa revista a los pocos sobrevivientes de su ejército, mientras la Malinche cose las banderas rotas.

Tenochtitlán ha quedado atrás. Atrás ha quedado la columna de humo que echó por la boca el volcán Popocatépetl, como diciendo adiós, y que no había viento que pudiera torcer.

Los aztecas han recuperado su ciudad. Las azoteas se erizaron de arcos y lanzas y la laguna se cubrió de canoas en pelea. Los conquistadores huyeron en desbandada, perseguidos por una tempestad de flechas y piedras, mientras aturdían la noche los tambores de la guerra, los alaridos y las maldiciones.

Estos heridos, estos mutilados, estos moribundos que Cortés está contando ahora, se salvaron pasando por encima de los cadáveres que sirvieron de puente: cruzaron a la otra orilla pisando caballos que se habian resbalado y hundido y soldados muertos a flechazos y pedradas o ahogados por el peso de las talegas llenas de oro que no se resignaban a $\operatorname{dejar}(G A L E A N O, 1991$, p. 64). 


\subsection{O resgate dos nomes}

Um forma de afirmar tanto a presença e como a participação de personagens que não só os integrantes do panteão de heróis, Galeano traz para o primeiro plano, alguns heróis do povo.

Nicaragua paga a los Estados Unidos una colosal indemnización por daños morales. Esos daños han sido infligidos por el caído presidente Zelaya, quien ofendió gravemente a las empresas norteamericanas cuando pretendió cobrarles impuestos.

Como Nicaragua carece de fondos, los banqueros de los Estados Unidos le prestan el dinero para pagar la indemnización. $Y$ como además de carecer de fondos, Nicaragua carece de garantía, el Secretario de Estado de los Estados Unidos, Philander Knox, envía nuevamente a los marines, que se apoderan de las aduanas, los bancos nacionales y el ferrocarril.

Benjamín Zeledón encabeza la resistencia. Tiene cara de nuevo y ojos de asombro el jefe de los patriotas. Los invasores no pueden derribarlo por soborno, porque Zeledón escupe sobre el dinero, pero lo derriban por traición.

Augusto César Sandino, un peón cualquiera de un pueblito cualquiera, ve pasar el cadáver de Zeledón arrastrado por el polvo, atado de pies y manos a la montura de un invasor borracho (GALEANO, 1994, ps. 3940).

Em todos os cantos e em todas as situações.

A bordo, toque de silencio. Un oficial lee la condena. Resuenan, furiosos, los tambores, mientras se azota a un marinero por cualquier indisciplina. De rodillas, atado a la balaustrada de cubierta, el condenado recibe su castigo a la vista de toda la tripulación. Los últimos latigazos, doscientos cuarenta y ocho, doscientos cuarenta y nueve, doscientos cincuenta, golpean un cuerpo en carne viva, bañado en sangre, desmayado o muerto.

Y estalla el motín. En las aguas de la bahía de Guanabara, se subleva la marinería. Tres oficiales caen, pasados a cuchillo. Lucen pabellón rojo los navíos de guerra. Un marinero raso es el nuevo jefe de la escuadra. Joao Cándido, el Almirante Negro, se alza al viento, en la torre de mando de la nave capitana, y los parias en rebelión le presentan armas.

Al amanecer, dos cañonazos despiertan a Río de Janeiro. El Almirante Negro advierte: tiene la ciudad a su merced, y si no se prohíbe el azote, que es costumbre de la Armada brasileña, arrasará Río sin dejar piedra sobre piedra. También exige una amnistía. Apuntan a los más importantes edificios las bocas de los cañones de los acorazados:

- Queremos respuesta ya y ya.

La ciudad, en pánico, obedece. El gobierno declara abolidos los castigos corporales en la Armada y dicta el perdón de los alzados. Joao Cándido se quita el pañuelo rojo del cuello y somete la espada. El almirante vuelve a ser marinero (GALEANO, 1994, p. 31). 


\subsection{Da resistência cultural}

Apesar de todos as tentativas dos colonizadores e, posteriormente, das elites locais baniram outras culturas que não a europeia ou norte-americano, a influência dos povos originários e dos descendentes dos escravos africanos não se extingue.

En Lima se indignan los artistas de caballete, los académicos y también los de vanguardia. Se ha otorgado el Premio Nacional de Arte a Joaquín López Antay, retablista de Huamanga, y eso es un escándalo. La artesanía no está mal, dicen los artistas peruanos, pero siempre y cuando no se salga de su sitio.

Los retablos de Huamanga, que empezaron siendo altares portátiles, han ido cambiando de personajes con el paso del tiempo. Los santos y los apóstoles han cedido su lugar a la oveja que da de mamar al cordero y al cóndor que vigila el mundo, al labrador y al pastor, al patrón castigador, al sombrerero en su taller y al cantador que acaricia, triste, su charango.

López Antay, el intruso en los selectos cielos del Arte, aprendió de su abuela india el oficio de retablos. Ella le enseñó a modelar santos, hace más de medio siglo; y ahora lo mira hacer, sentada, tranquila, desde la muerte.(GALEANO, 1986, p. 204).

A língua apesar de maltratada ainda resiste. Não apenas o guarani, mas o aymara, o tupy e tantas outras. Só no México seriam mais de 40 línguas, além do castelhano.

Del Paraguay aniquilado, sobrevive la lengua.

Misteriosos poderes tiene el guaraní, lengua de indios, lengua de conquistados que los conquistadores hicieron suya. A pesar de prohibiciones y desprecios, el guaraní es la lengua nacional de esta patria en escombros y lengua nacional seguirá siendo aunque la ley no quiera. Aquí el mosquito se seguirá llamando uña del Diablo y caballito del Diablo la libélula. Seguirán siendo fuegos de la luna las estrellas y el crepúsculo la boca de la noche.

En guarani han pronunciado los soldados paraguayos su santo y seña y sus arengas, mientras duró la guerra, y en guaraní han cantado. En guarani callan, ahora, los muertos (GALEANO, 1994, p. 181).

\subsection{Sobre as mulheres}

Poucos nomes aparecem e na maioria das vezes como coadjuvantes apenas. Atrás de um grande homem existe sempre uma grande mulher, escondida do mundo em casa. Mas na verdade, muitas talharam seus próprios caminhos.

Ella consagra la tierra que pisa. Jacinta de Siqueira, africana del Brasil, es la fundadora de esta villa del Príncipe y de las minas de oro en los barrancos de Quatro Vintens. Mujer negra, mujer verde, Jacinta se abre y se cierra como planta carnicera tragando hombres y pariendo hijos de todos los colores, en este mundo sin mapa todavía. Avanza Jacinta, rompiendo selva, a la cabeza de los facinerosos que vienen a lomo de 
mula, descalzos, armados de viejos fusiles, y que al entrar en la mina dejan la conciencia colgada de una rama o enterrada en una ciénaga: Jacinta, nacida en Angola, esclava en Bahía, madre del oro de Minas Gerais (GALEANO, 1994, p. 21).

Se fosse preciso, iam a luta

En esta guerra, que ha hecho crujir la tierra con dolores de parto, Micaela Bastidas no ha tenido descanso ni consuelo. Esta mujer de cuello de pájaro recorría las comarcas haciendo más gente y enviaba al frente nuevas huestes y escasos fusiles, el largavistas que alguien habia pedido, hojas de coca y choclos maduros. Galopaban los caballos, incesantes, llevando y trayendo a través de la serranía sus órdenes, salvoconductos, informes y cartas. Numerosos mensajes envió a Túpac Amaru urgiéndolo a lanzar sus tropas sobre el Cuzco de una buena vez, antes de que los españoles fortalecieran las defensas y se dispersaran, desalentados, los rebeldes. Chepe, escribía, Chepe, mi muy querido: Bastantes advertencias te di...

Tirada de la cola de un caballo, entra Micaela en la Plaza Mayor del Cuzco, que los indios llaman Plaza de los Llantos. Ella viene dentro de una bolsa de cuero, de esas que cargan yerba del Paraguay. Los caballos arrastran también, rumbo al cadalso, a Túpac Amaru y a Hipólito, el hijo de ambos. Otro hijo, Fernando, mira (GALEANO, 1994, p. 62).

Aonde os homens recuaram, elas se mantiveram fortes até o fim.

En Cochabamba, muchos hombres han huido. Mujeres, ninguna. En la colina, resuena el clamoreo. Las plebeyas cochabambinas, acorraladas, pelean desde el centro de un círculo de fuego. Cercadas por cinco mil españoles, resisten disparando rotosos cañones de estaño y unos pocos arcabuces; y combaten hasta el último alarido.

La larga guerra de la independencia recogerá los ecos. Cuando la tropa afloje, el general Manuel Belgrano gritará las palabras infalibles para devolver templanzas y disparar corajes. El general preguntará a los soldados vacilantes: ¿Están aquí las mujeres de Cochabamba? (GALEANO, 1994, p. 101)

Apesar de todo mal, ainda continua lutando.

Ella es una india maya-quiché, nacida en la aldea de Chimel, que recoge café y corta algodón en las plantaciones de la costa desde que aprendió a caminar. En los algodonales vio caer a dos de sus hermanos, Nicolás y Felipe, los más chiquitos, y a su mejor amiga, todavía a medio crecer, todos sucesivamente fulminados por los pesticidas.

El año pasado, en la aldea de Chajul, Rigoberta Menchú vio cómo el ejército quemaba vivo a su hermano Patrocinio. Poco después, en la embajada de España, también su padre fue quemado vivo junto con otros representantes de las comunidades indias. Ahora, en Uspantán, los soldados han liquidado a su madre muy de a poco, cortándola en pedacitos, después de haberla vestido con ropas de guerrillero.

De la comunidad de Chimel, donde Rigoberta nació, no queda nadie vivo. 
A Rigoberta, que es cristiana, le habian enseñado que el verdadero cristiano perdona a sus perseguidores y reza por el alma de sus verdugos. Cuando le golpean una mejilla, le habian enseñado, el verdadero cristiano ofrece la otra.

- Yo ya no tengo mejilla que ofrecer - comprueba Rigoberta (GALEANO, 1986, p. 230).

Um comandante não se rende a uma mulher?

A la espalda, un abismo. Por delante y a los costados, el pueblo armado acometiendo. El cuartel La Pólvora, en la ciudad de Granada, último reducto de la dictadura, está al caer.

Cuando el coronel se entera de la fuga de Somoza, manda callar las ametralladoras. Los sandinistas también dejan de disparar.

Al rato se abre el portón de hierro del cuartel y aparece el coronel agitando un trapo blanco.

- ¡No disparen!

El coronel atraviesa la calle.

- Quiero hablar con el comandante.

Cae el pañuelo que cubre la cara:

- La comandante soy yo - dice Mónica Baltodano, una de las mujeres sandinistas con mando de tropa. - ¿Que qué?

Por boca del coronel, macho altivo, habla la institución militar, vencida pero digna, hombría del pantalón, honor del uniforme:

- ¡Yo no me rindo ante una mujer! - ruge el coronel. Y se rinde (GALEANO, 1986, p. 224).

\subsection{Da violência contra os escravos à violência contra os operários}

A violência com que os colonizadores trataram primeiro aos povos originários, depois aos escravos africanos permanece na desumanidade do tratamento despendido aos operários.

Banderas de varios países encabezan la marcha de los obreros del salitre, a través del cascajoso desierto del norte de Chile. Miles de obreros en huelga y miles de mujeres y niños caminan hacia el puerto de Iquique, coreando consignas y canciones.

Cuando los obreros ocupan Iquique, el ministro del Interior dicta orden de matar. Los obreros, en continua asamblea, deciden aguantar a pie firme y sin arrojar ni una piedra. José Briggs, jefe de la huelga, es hijo de un norteamericano, pero se niega a pedir protección al cónsul de los Estados Unidos.

El cónsul del Perú intenta llevarse a los obreros peruanos. Los obreros peruanos no abandonan a sus compañeros chilenos. El cónsul de Bolivia quiere salvar a los obreros bolivianos. Los obreros bolivianos dicen:

- Con los chilenos vivimos, con los chilenos morimos. 
Las ametralladoras y los fusiles del general Roberto Silva Renard barren a los huelguistas desarmados y dejan el tendal.

El ministro Rafael Sotomayor justifica la carnicería en nombre de las cosas más sagradas, que son, en orden de importancia: la propiedad, el orden público y la vida (GALEANO, 1986, p. 24).

\subsection{Da polifonia de vozes}

A história narrada por Galeano, apresenta uma permanente tensão entre aqueles que detêm o poder e aqueles que resistem à submissão. No princípio, essa tensão estava restrita a relação entre os povos originários e os colonizadores e se expressava por meio da negação da cultura dos povos originários. A renomeação do continente, de suas florestas, de seus rios e de seus habitantes demonstra a força dos europeus sobre o seu achado. Aos habitantes primeiros, não há nenhum direito, a não ser, se converter à fé verdadeira e declarar lealdade aos reis de Espanha.

Em um segundo momento, esse processo de desumanização alcança aos novos moradores da América, os escravos vindos da África. A desumanização prossegue e faz-se perceber na brutalidade dos castigos físicos. A negação das diferenças, a diversidade étnica-cultural dos povos originários reduzidas à homogeneidade do termo índio, a homogeneização das diversas etnias vindas da África pelo termo negro. Contudo, mesmo diante da violência que se abate sobre os povos originários, os escravos e, posteriormente, sobre os mestiços, a submissão nunca foi completa, nem chegou perto de ser. Esse intento só fora alcançado quando do aniquilamento físico e cultural de um determinado grupo étnico.

Esse processo de negação e a vontade de dispor do Outro como bem entender, reflete-se no nome América Latina e, por conseguinte, em nossa identidade. Não há espaço para outra cultura ao seu lado, a cultura europeia encontra-se acima das demais, as demais componentes culturas servem apenas como lastro ao desenvolvimento de nossa região.

A la Exposición Universal de París llegan los óleos sobre tela que el Ecuador envía. Todos los cuadros son copias exactas de las obras más famosas de la pintura europea. El catálogo exalta a los artistas ecuatorianos, que si no tienen gran valor de originalidad, tienen al menos el mérito de reproducir, con fidelidad notable, las obras maestras de la escuela italiana, española, francesa y flamenca.

Mientras tanto, otro arte florece en los mercados indios y en los suburbios populares del Ecuador. Es la despreciada tarea de manos capaces de transformar en hermosura el barro y la madera y la paja, la pluma de pájaro y la concha de mar y la miga de pan. Ese arte se llama, como pidiendo disculpas, artesanía. No lo hacen los académicos, sino las pobres gentes que comen corazones de pulga o tripas de mosquito (GALEANO, 1994, p. 179). 
As culturas não-europeis ao serem negadas são incorporadas de maneira subalterna, nessa condição resistem ao processo colonizador. Essa contradição se reflete na escolha e na manutenção do nome América Latina até hoje. 


\section{Considerações Finais}

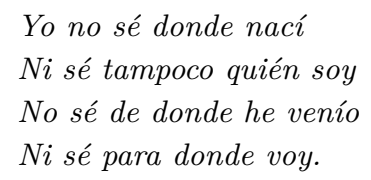

Coplas Populares de Boyacá,

Colombia

O processo de constituição da identidade latino-americana se desenvolve atrelado ao processo de formação do continente Americano como vimos apontando. A escolha do nome América Latina reflete a correlação de forças do período de independência e consolidação das jovens repúblicas, contudo, incorpora preconceitos vindos ainda do período colonial. Ao mesmo tempo que valoriza um determinado componente cultural em detrimento dos demais. O elemento cultural europeu torna-se o modelo a ser alcançado em sua plenitude. Os demais são obstáculos para o seu desenvolvimento. Essa compreensão relaciona-se ao modo como as contradições socais se dão em nosso continente. As maneiras como a negação ou a ocultação do Outro acontecem em nossa história e como o nome América Latina reflete esse processo torna-se fácil afirmar a necessidade de sua substituição. Contudo, qual seria a melhor denominação para o nosso continente?

Como quer Adorno (1993), a nomeação de uma determinada nação, além de reforçar esteriótipos pode manter nas sombras o que possui de melhor, aqueles que não se ajustam ao sujeito coletivo.

No es seguro ni mucho menos que exista algo como 'los alemanes'o 'lo alemán' o cosa parecida, en otras naciones. Lo verdadero y lo mejor em todo pueblo es más bien lo que no se ajusta al sujeto coletivo, y que llegado el caso, se le opone. La formación de estereotipos, por el contrário, favorece el narcismo colectivo (ADORNO, 1993, p. 96)

O nome América Afro-Latina, refere-se aos países com grande influência da cultura a africana. Então, seria utilizada apenas para designar os países em que a influência cultural da África seja significativa. De outro lado, a cultura dos povos originários, continuam a ser eclipsada nessa denominação.

A construção de uma nova denominação não faz sentido ocorrer pela busca de um nome que simplesmente inclua em si os vários povos que compõem e que vem compondo essas terras. Se a denominação América Latina é insuficiente para representar nossa diversidade, quando não representa o massacre perpetrado ao longo da empresa civilizatório. 
Entretanto o nome América Latina é fruto do próprio processo histórico de sua constituição. A configuração de um outro nome que de conta e possa expressar essa diversidade deverá ser fruto e buscado desse próprio processo histórico. Essa é uma tarefa histórica daqueles que buscam uma maior integração social do continente.

Em Memória do Fogo, Galeano se esforça para desvelar a diversidade e as contradições que compõe a nossa região. Contradições essas que se mostram no centro do processo identitário. Se existe uma possibilidade de se afirmar a ideia de uma identidade latino-americana, ela se encontra presente nesta obra de Galeano, naquilo que ela revela de diverso em nossa constituição. Uma identidade fragmentária que se recusa a homogeinização e totalização.

Se é no processo histórico que se abre a possibilidade de uma outra denominação dessas terras. A América Latina vem se constituíndo na resistência dos seus povos.Então que seja um nome que se refira ao lugar que habitamos. Nesse sentido, podemos sugerir que habitamos uma terra madura, Abya Ayla. Um nome que se referes ao lugar onde vivemos. 


\section{Referências}

ADORNO, T. Consignas. Buenos Aires: Amorrotu editores, 1993.

ANDREWS, G. R. América Afro-Latina, 1800-2000. São Carlos: EdUFSCar, 2007.

ARDAO, A. Génesis de la idea y el nombre de América Latina. Mexico: Centro de Estudios Latinoamericanos Rómulo Gallegos, 1980.

ARDAO, A. Nuestra América Latina. Montevidéo: ediciones de la Banda Oriental, 1986. v. 1 .

ARGEnTINA, M. de Educación de la R. Voces: Eduardo Galeano. SD. Disponível em: $<$ http://www.encuentro.gov.ar/sitios/encuentro/programas/ver?rec_id=106379>.

AZEVEDO, F. L. N. d. Raízes da america latina: Da colonização à formação dos estados nacionais. In: Francisca L Nogueira de Azevedo e John Manuel Monteiro org. América 500 anos Raízes da América Latina. São Paulo: EdUSP, 1996. v. 5, cap. Prefácio, p. $19-23$.

BARRENTO, J. Limiares sobre Walter Benjamin. Florianópolis: ufsc, 2013.

BENJAMIN, W. Magia e técnica, arte e política: ensaios sobre literatura e história da cultura (Obras escolhidas; v. 1). São Paulo: Editora Brasiliense, 1994. v. 1.

BENJAMIN, W. Passagens. Belo Horizonte: Editora UFMG, 2006.

BETHEL, L. O brasil e a ideia de 'américa latina' em perspectiva histórica. Estudos Históricos, p. 289-321, 2009.

CANDIDO, A. Formação da Literatura Brasileira. $3^{\text {a }}$. ed. São Paulo: São Paulo, Livraria Martins Editora, 1969. v. 1 e 2.

DUSSEL, E. 1492 el encubrimiento del otro: Hacia el origen del "mito de la modernidad". Plural, 1994.

EBC. Eduardo Galeano comenta Veias abertas da América Latina. 2014. Agencia Brasil de Comunicações. Disponível em: < http://agenciabrasil.ebc.com.br/cultura/noticia/ 2014-04/galeano-diz-que-realidade-mudou-e-que-nao-releria-seu-livro-mais-conhecido> .

FARRET, R. L.; PINTO, S. R. América latina: da construção do nome à consolidação da ideia. Topoi, v. 12, n. 23, p. 30-42, 2011.

GAGNEBIN, J.-M. Walter Benjamin e os cacos da história. São Paulo: Brasiliense, 1982 .

GAGNEBIN, J.-M. História e narrativa em Walter Benjamin. São Paulo: Perspectiva São Paulo, 1994.

GAGNEBIN, J.-M. Prefácio. In: Benjamin, Walter. Magia e técnica, arte e política: ensaios sobre literatura e história da cultura (Obras escolhidas; v. 1). São Paulo: Editora Brasiliense, 1994. v. 1, p. 7-21. 
GALEANO, E. As Veias abertas da América Latina. 1. ed. Rio de Janeiro: Paz e Terra, 1972.

GALEANO, E. Dias e Noites de Amor e Guerra. Rio de Janeiro: Paz e Terra, 1978.

GALEANO, E. Memoria del fuego vol.3: El siglo del viento. Madrid: XXI Siglo Veintiuno Editores, 1986.

GALEANO, E. Memoria del fuego vol. 1: Los nacimientos. 19. ed. Madrid: Siglo XXI, 1991. v. 1.

GALEANO, E. Memoria del fuego vol. 2: las caras y las máscaras. 14. ed. Madrid: Siglo XXI de España Editores, SA, 1994. v. 2.

GALEAnO, E. O livro dos abraços. 9. ed. Porto Alegre: L \&amp; Pm, 2002.

GALEANO, E. H. Vozes e Crônicas: "Che"e outras histórias. São Paulo: Global/Versus, 1978.

KOVACIC, F. La Biografia. Montevidéo: Ediciones B, 2015.

LARRAÍN, J. La identidad latinoamericana: teoría e historia. Estudios Públicos, CEP Santiago, v. 55, p. 31-64, 1994.

LEITE, D. M. O caráter nacional brasileiro: história de uma ideologia. São Paulo: Unesp, 2002.

LISBOA, A. de M. De américa a abya yala-semiótica da descolonização. Revista de Educação Pública, v. 23, n. 53/2, p. 501-531, 2014.

MIGNOLO, W. D. La idea de América Latina: la herida colonial y la opción decolonial. Barcelona: Gedisa Editorial SA, 2007.

MORA, E. A. El origen del nombre américa latina y la tradición católica del siglo xix. Anuario Colombiano de Historia Social y de la Cultura, v. 40, n. 1, p. 213-241, 2012.

MORSE, R. M. O multiverso da identidade latino-americana. In: BETHELL, Leslie org. A América Latina após 1930: Estado e Politica. São Paulo: EDUSP, 2009. v. 8, cap. 1, p. 19-161.

OLIVEIRA, A. Q. de. Quando se rompe o silêncio: o livro as veias abertas da américa latina e sua trajetória no brasil. Temporalidades - Revista Discente do Programa de Pós-Graduação da UFMG, v. 5, Jan/Abr 2013. Disponível em: <http://www.fafich.ufmg.br/temporalidades/pdfs/09p6.pdf>.

PAIVA, G. J. de. Identidade psicossocial e pessoal como questão contemporânea. Psico, v. 38 , n. $1,2007$.

PERRONE-MOISÉS, L. Paradoxos do nacionalismo literário na américa latina. Estudos Avançados, SciELO Brasil, v. 11, n. 30, p. 245-259, 1997.

PORTO-GONÇALVES, C. W. Entre américa e abya yala-tensões de territorialidades. Desenvolvimento e Meio Ambiente, n. 20, p. 25-30, jul./dez. 2010. 
RAMOS, V. H. La identidad latinoamericana: proceso contradictorio de su construccióndeconstrucción-reconfiguración dentro de contextos globales. Universitas Humanística, n. 73, p. $15-58,2012$.

REIS, M. F. O debate intelectual uruguaio sobre a américa latina e os eua do pós-segunda guerra: Entre democracias e revoluções. História Revista, v. 13, n. 2, p. 462-482, jul./dez. 2009.

RIVA, H. Memoria viviente de América Latina: la obra de Eduardo Galeano. Buenos Aires: Editorial Lumen, 1996.

SARLO, B. Sete ensaios sobre Walter Benjamin e um lampejo. Rio de Janeiro, RJ: UFRJ, 2012.

SOMMER, D. Fiç̧̃es de Fundação: os romances nacionais da América Latina. Belo Horizonte: Editora UFMG, 2004.

TODOROV, T. A conquista da América: a questão do outro. $3^{\mathrm{a}}$. ed. São Paulo: Martins Fontes, 2003. v. 258.

UREÑA, P. H. Las corrientes literarias en la América Hispánica. Mexico: Fondo de cultura económica, 1949. v. 9.

UREÑA, P. H. Historia de la cultura en la América hispánica. 2a . ed. Mexico: Fondo de cultura económica, 2001. v. 28.

ZEA, L.; LATINA, U. d. U. de A. América Latina, largo viaje hacia si misma. Ciudad de Mexico: Universidad Nacional Autónoma de México, Coordinación de Humanidades, Centro de Estudios Latinoamericanos, Facultad de Filosofía y Letras; Unión de Universidades de América Latina, 1978. 


\title{
ANEXO A - Las dos Americas
}

\author{
"Yo lo juro también, y en este \\ instante \\ Yo me siento mayor, dadme una \\ lanza, \\ Ceñidme el casco fiero y refulgente, \\ Volemos al combate, a la venganza, \\ $Y$ el que niegue su pecho a la \\ esperanza. \\ Hunda en el polvo la cobarde frente." \\ Quintana
}

I

Rica, potente, activa y venturosa

Se levanta de América en el Norte

Una nación sin reyes y sin corte,

De sí señora - esclava de la ley;

Débil ayer, escasa de habitantes,

Al ver que Albión su libertad robaba,

¡Atrás, gritó: la servidumbre acaba,

Porque hoy un Pueblo se proclama rey!

Y aprestado a la lid, con faz serena,

A luchar se lanzó; lidió valiente;

Triunfó do quiera; libre, independiente,

República al instante apellidó.

$\mathrm{Y}$ ese pueblo tan fiero en el combate,

Prudente se mostró tras la victoria,

Y su primera página de gloria

Fue que en el Orden Libertad basó.

$\mathrm{Su}$ ley primera hallóse defectuosa.

Porque imposible la existencia hacía

Del gobierno: -Ya asoma la anarquía,

Gritaron los patriotas sin cesar;

Las plazas colma el pueblo soberano,

Y otra Constitución, prudente, vota:

Así la nave que el turbión azota,

Experto capitán logra salvar.
II

Vástagos de esos hombres valerosos

Que la tierra de Europa abandonaron,

Porque en sus playas libertad no hallaron

Para elevar altares a su Dios;

Que atravesando los airados mares,

De la virgen América en la orilla

Sembraron del Derecho la semilla,

Que ricos frutos produjera en pos:

Washington, Caroll, Hamilton y Franklin,

Nietos de esos varones venerables,

Libertad sobre basas perdurables

Quisieron en su patria cimentar;

Amantes del Deber y la justicia,

Alzaron del Derecho la bandera:

¡Santa Revolución! Fue la primera

Que llamara los pueblos a reinar.

Sin era de terror - sin proscripciones-

Las leyes de Moral siempre observadas,

De América en las tierras dilatadas,

Se alzó del libre el ancho pabellón.

Las leyes de ese pueblo fueron sabias:

Libertad para sí -con los extraños

Paz y amistad; así tras pocos años

Potente y rica se mostró la Unión. 
III

En tanto que del Norte en las riberas

La ley del Cristo por do quier triunfaba,

Allá en el Sur la América soñaba

De libertad un bello porvenir.

Sonó la hora. Bravos se lanzaron

A lidiar por su patria los guerreros;

Del Plata al Orinoco los aceros

De mil valientes viéronse blandir

. Y lucharon constantes. Los reveses

Su valor aumentaban, su energía;

El Dios de las batallas prometía

A esfuerzos tan heróicos, galardón.

Y eran pocos, y escasos de recursos,

Lidiaban con soldados aguerridos;

Mas ora vencedores, ya vencidos,

Jamás desfalleció su corazón.

Mil triunfos sus proezas coronando,

Los Andes aclamaron su victoria;

Ante el mundo la América con gloria

Mostróse libre, independiente al fin.

El Plata vio las huestes triunfadoras,

Por do quiera escuchóse con arrobo

La historia de Maipú, de Carabobo,

De Boyacá, Pichincha y de Junin.

IV

México al Norte. Al Sur las otras hijas

Que a la española madre rechazaron,

De Washington la patria contemplaron

Como hermana mayor, como sostén;

Copiaron con fervor sus sabias leyes,

Por tipo la tomaron, por modelo;

Buscaron su amistad con vivo anhelo,

Y su alianza miraron como un bien.

Ella, entre tanto, altiva desdeñaba

La amistad aceptar de sus hermanas;

El gigante del Norte, como enanas

Miraba las Repúblicas del Sud.
Fue preciso que Albión las inscribiera

En el libro en que inscribe las naciones,

Para que honrara entonces sus pendones

La nación sin niñez, sin juventud.

V

Mas tarde, de sus fuerzas abusando,

Contra un amigo pueblo a guerra llama;

$\mathrm{Su}$ suelo invade, ejércitos derrama

Por sus campos y bella capital.

La tierra mexicana estaba entonces

En contrarias facciones dividida:

-jAy del pueblo que en guerra fratricida

Oye el grito de guerra nacional!

En vano fue que sus mejores hijos

Valientes se lanzaran al combate,

Que el enemigo en su carrera abate

Las huestes mexicanas, su pendón;

El yankee odiando la española raza,

Altivo trata al pueblo sojuzgado,

Y del campo, encontrándose adueñado,

Se adjudica riquísima porción...

VI

"Cuanto es útil, es bueno», así creyendo,

La Unión americana da al olvido

La justicia, el Deber, lo que es prohibido

Por santa ley de universal amor;

Y convirtiendo la Moral en cifras,

Lo provechoso como justo sigue;

El Deber ¡qué le importa si consigue

Aumentar su riqueza y su esplendor!

A su ancho pabellón estrellas faltan,

Requiere su comercio otras regiones;

Mas flotan en el Sur libres pendones

-¡Que caigan! dice la potente Unión.

La América central es invadida,

El Istmo sin cesar amenazado,

Y Walker, el pirata, es apoyado 
Por la del Norte, ipérfida nación!

El seno de la América valiente

Desgarran ya sus nuevos opresores;

Hoy sufre Nicaragua los horrores

De una ruda y sangrienta esclavitud:

Tala los campos el audaz pirata,

Pone fuego a las villas y ciudades;

¡Y aprueba sus delitos y maldades

Su patria, tierra un tiempo de virtud!

VI

¡Oh, santa Libertad! tus hijos vuelan

A encadenar sus débiles hermanos;

De la tierra do reinas, los tiranos

Salen llenos de saña y de furor.

Ese pueblo gigante que pudiera

A los débiles pueblos dar ayuda,

Los odia, los invade, y guerra cruda

Les declara, ¡volviéndose traidor!

Su móvil, la ambición y la codicia;

Sus medios -ya la fuerza, ya el engaño;

Y no vé que trabaja así en su daño,

Al revivir la más odiosa edad.

La Europa no se duerme, sino asecha

La ocasión de extender su despotismo:

¡La libre Unión preparará el abismo

En que se hunda al fin la libertad!...

La Unión está minada, esclavos tiene:

El Sur y el Norte a separarse tienden;

Se agravan sus cuestiones, y se encienden

Más que nunca sus hombres al lidiar.

Ya los preludios de civil contienda

Sangrientos en su suelo aparecieron;

La lucha se aplazó; mas todos vieron

Que no muy tarde volverá a empezar.

La moral de ese pueblo es relajada;

Sólo el comercio salva su existencia;

Mas, lleno de ambición, en su demencia,

Para sí la confianza va a destruir.
La América del Sur sus puertos le abre,

De sus riquezas a gozar lo invita,

¡Y él, entre tanto, pérfido medita

Privarla de su bello porvenir!

VII

I ¿Dónde está de esos pueblos valerosos

El belicoso ardor y la energía?

Ellos supieron alcanzar un día

Patria, derechos, libertad y honor.

Hoy entregados a intestinas luchas,

¿Sufrirán la invasión del extranjero,

Sin requerir valientes el acero,

Y a la lid aprestarse con vigor?

¡No! que esa raza noble, generosa,

Exenta está de sórdido egoísmo,

$\mathrm{Y}$ al escuchar la voz del patriotismo,

Se distingue con hechos sin igual,

La tierra de la América española

No ha brotado ni bajos, ni traidores;

Y se verán sus tercios vencedores,

Si le provocan guerra nacional.

Los que ayer arrollaron denodados

Las huestes castellanas por do quiera,

Sostendrán el honor de su bandera

Y el nombre de la América del Sud;

Sus hijos, de esas glorias herederos,

El brillo aumentarán de nuestra historia,

Que luchar por la patria y por su gloria,

Sabe la americana juventud.

IX

Mas aislados se encuentran, desunidos,

Esos pueblos nacidos para aliarse:

La unión es su deber, su ley amarse:

Igual origen tienen y misión;

La raza de la América latina,

$\mathrm{Al}$ frente tiene la sajona raza,

Enemiga mortal que ya amenaza 
Su libertad destruir y su pendón.

La América del Sur está llamada

A defender la libertad genuina,

La nueva idea, la moral divina,

La santa ley de amor y caridad.

El mundo yace entre tinieblas hondas:

En Europa domina el despotismo,

De América en el Norte, el egoísmo,

Sed de oro e hipócrita piedad.

Tiempo es que esa Virgen que se alza

Entre dos Océanos arrullada

Y por los altos Andes sombreada,

Deje su voz profética escuchar.

El cielo que la dio bellezas tantas,

La señaló un magnífico destino:

Nueva Vestal, conservará el divino

Fuego que nunca deberá cesar.

Ella será la que levante firme

Templo a la Libertad y a los Derechos,

Al rodar carcomidos y deshechos

Los palacios que albergan el error;

Que sus selvas y llanos dilatados

A la Razón ofrecerán altares,

Y por sus playas cambiarán sus lares

Cuantos anhelen libertad, amor.

Sacerdotisa del moderno tiempo,

Derramará la luz de la esperanza;

Bajo su manto alcanzará bonanza

La afligida, doliente humanidad.

En sus bellos, edénicos jardines,

Bajo su sol ardiente y amoroso,

Se alzará un himno eterno, misterioso,

¡Al Orden, la Concordia y Libertad!

Reinarán los gobiernos de derecho;

Esclavo de la Ley el ciudadano,

De sus actos perfecto soberano,

Reglará sus acciones la razón.

Se acabarán los lindes egoístas

Que separan naciones de naciones;
Y en lugar de la voz de los cañones,

Se escucharán cantares a la Unión.

A cima llevará tan grandes bienes

La América del Sur con solo unirse;

Si ha padecido tanto al dividirse,

¿Por qué compacta no se muestra al fin?

No solo su ventura -la del mundo,

De su quietud, de su concordia pende;

Su unión será cual faro que se enciende

En noche borrascosa, en el confín.

¡Hermoso continente bendecido

Por la Diestra de suma Providencia:

Si lo quieres, el bien de tu existencia

Fácil lo encuentras -te lo da la UNIÓN!

Eso te falta para ser dichoso,

Rico, potente, grande, respetado;

¡UNIÓN y el paraíso tan soñado

Bajo tu cielo está, por bendición!

Un mismo idioma, religión la misma,

Leyes iguales, mismas tradiciones:

Todo llama esas jóvenes naciones

Unidas y estrechadas a vivir.

¡América del Sur! ¡ALIANZA, ALIANZA

En medio de la paz como en la guerra;

Así será de promisión tu tierra:

La ALIANZA formará tu porvenir!

$\mathrm{X}$

¿Mas qué voces se escuchan por do quiera?

¿Qué expresan esos gritos de agonía?

¿Qué quiere aquella turba audaz, impía,

Que recorre la América central?

Qué ¡mancillado el suelo americano

Por un puñado de invasores viles!

¿Dónde, do están los pechos varoniles

De la española raza tan marcial?

¡A las armas! ¡Corramos al combate!

¡A defender volemos nuestra gloria,

A salvar de la infamia nuestra historia, 
A sostener la Patria y el Honor!

El Norte manda sin cesar auxilios

A Walker, el feroz aventurero,

Y se amenaza el continente entero,

¡Y se pretende darnos un señor!

¡A la lid! Mientras alienten nuestros pechos,

Mientras circule sangre en nuestras venas,

Repitamos, si es fuerza, las escenas

De Ayacucho, de Bárbula y Junín.

El pueblo que pretende encadenarnos,

Nos encuentre cerrados en batalla,

Descargándole pólvora y metralla,
¡Al claro son de bélico clarín!

La paz es santa; mas si mueve guerra

Un pueblo audaz a un pueblo inofensivo,

La guerra es un deber -es correctivo,

Y tras ella la paz se afirmará.

¡UNIÓN! ¡UNIÓN que ya la lucha empieza,

Y están nuestros hogares invadidos!

¡Pueblos del Sur, valientes, decididos,

El mundo vuestra ALIANZA cantará!

Venecia, 26 de setiembre de 1856

José María Torres Caicedo 